\title{
WestVirginiaUniversity
}

THE RESEARCH REPOSITORY @ WVU

Graduate Theses, Dissertations, and Problem Reports

2010

\section{The Politics and Policy of Small City Downtown Development}

Thomas K. Bias

West Virginia University

Follow this and additional works at: https://researchrepository.wvu.edu/etd

\section{Recommended Citation}

Bias, Thomas K., "The Politics and Policy of Small City Downtown Development" (2010). Graduate Theses, Dissertations, and Problem Reports. 3147.

https://researchrepository.wvu.edu/etd/3147

This Dissertation is protected by copyright and/or related rights. It has been brought to you by the The Research Repository @ WVU with permission from the rights-holder(s). You are free to use this Dissertation in any way that is permitted by the copyright and related rights legislation that applies to your use. For other uses you must obtain permission from the rights-holder(s) directly, unless additional rights are indicated by a Creative Commons license in the record and/ or on the work itself. This Dissertation has been accepted for inclusion in WVU Graduate Theses, Dissertations, and Problem Reports collection by an authorized administrator of The Research Repository @ WVU.

For more information, please contact researchrepository@mail.wvu.edu. 


\title{
The Politics and Policy of Small City Downtown Development
}

\author{
Thomas K. Bias
}

Dissertation submitted to the Eberly College of Arts and Sciences at West Virginia University in partial fulfillment of the requirements for the degree of

\author{
Doctor of Philosophy \\ In \\ Political Science
}

\author{
Kevin Leyden, Ph.D., Chair \\ Erin Cassese, Ph.D. \\ Robert Duval, Ph.D. \\ Philip Michelbach, Ph.D. \\ Brian Cushing, Ph.D. \\ Department of Political Science \\ Morgantown, West Virginia \\ 2010
}

Keywords: Community Development; Public Policy; Local Politics

Copyright 2010 Thomas K. Bias 


\section{ABSTRACT \\ The Politics and Policy of Small City Downtown Development Thomas K. Bias}

Many theories on successful small city development and revitalization efforts hinge on three major areas; Policies and programs, quality of life, and strong coalitions between government, non-profit groups, local business, and residents. This dissertation examines the affects that government policies and programs (e.g., Main Street programs, zoning laws, etc.) have on the success of small city development and revitalization efforts. Using original survey data from a sample of key small city policy makers across the United States, this dissertation explores how perceptions of small city downtowns are influenced by government efforts to improve them. Regression analysis is employed to determine these relationships. Perceptions of the overall quality of life are also addressed. The dissertation concludes that mixed-use zoning, programs such as Main Street USA, cooperation among key stakeholders, and the perceptions of quality of life in a given area have a highly significant impact on the "success" of downtowns. The implications found here can aid cities striving to improve their downtowns and the quality of life for the people who live there. 


\section{Dedication}

This dissertation is dedicated to my wife Sarah Bias, my son Xavier Bias, my grandmother Mary Bias, and parents Tom and Cheryl Bias for all their support over the years during my education and the patience to wait for me to finish. 


\section{Acknowledgements}

This dissertation would not be possible without a number of professional colleagues and mentors who have provided such a wonderful education over the years. First and foremost, I would like to thank Dr. Kevin Leyden for all the opportunities he has given me at the Institute for Public Affairs. His help and encouragement has allowed me multiple publications, research projects, and opened me to a new line of research and understanding of downtown development, public health, and survey methodologies. Dr. Leyden's guidance has made this dissertation a reality and provided a wealth of expertise in the literature presented here. Dr. Robert Duval and Dr. Erin Cassese have provided me with immeasurable insight into research methods. I would also like to thank

Dr. Philip Michelbach and Dr. Brian Cushing for their suggestions and recommendations to make this dissertation a polished product. Finally, I need to thank Dr. Abraham Goldberg for sharing his experiences with the dissertation process and helping to keep me on track to finish. 


\section{Table of Contents}

$\begin{array}{lc}\text { Abstract } & \text { ii } \\ \text { Dedication } & \text { iii } \\ \text { Acknowledgements } & \text { iv } \\ \text { Table of Contents } & \text { V } \\ \text { List of Tables } & \text { vi } \\ \text { List of Figures } & \text { viii } \\ \text { Chapter 1: Introduction to Downtown Development Policy } & 1 \\ \text { Chapter 2: The Survey Instrument } & 59 \\ \text { Chapter 3: A Model of Successful Downtowns } & 113 \\ \text { Chapter 4: Conclusions } & 135 \\ \text { Bibliography } & 147 \\ \text { Appendix I: Survey Instrument and Cover Letter } & 153 \\ \text { Curriculum Vitae } & 157\end{array}$ 


\section{List of Tables}

Table 1.1: List of Differences between Large and Small Cities 5

Table 1.2: Policy Tools to Help Manage Urban Growth 23

Table 1.3: Elements of the Literature $\quad 51$

Table 2.1: Official Downtown $\quad 77$

Table 2.2: General Downtown Area $\quad 77$

Table 2.3: Downtown Zoning 78

Table 2.4: Overall Rating of Downtown $\quad 79$

Table 2.5: Cooperation $\quad 80$

Table 2.6: Tax Increment Financing 81

Table 2.7: Real Estate Tax Abatements $\quad 81$

Table 2.8: User Fees $\quad 82$

Table 2.9: Developer Fees $\quad 82$

Table 2.10: Tax Credits $\quad 82$

Table 2.11: Debt Financing 83

Table 2.12: Main Street Program 83

Table 2.13: Formal Policy Encouraging Development 83

Table 2.14: Federal Grants $\quad 84$

Table 2.15: State/Local Grants $\quad 84$

Table 2.16: Festivals and Events $\quad 85$

Table 2.17: Eminent Domain $\quad 85$

Table 2.18: Development Moratoria 86

Table 2.19: Community Development Corporations 86

Table 2.20: Non-Profit Grants $\quad 87$

Table 2.21: Historic Society/Trust Program 87

Table 2.22: Direct Subsidies for Businesses Downtown 88

Table 2.23: Indirect Subsidies for Businesses Downtown 88

Table 2.24: Direct Subsidies for Businesses outside Downtown 88

Table 2.25: Indirect Subsidies for Businesses outside Downtown 89

Table 2.26: Urban Growth Management Policy 90

Table 2.27: Urban Growth Boundaries $\quad 91$

Table 2.28: Urban Service Boundaries $\quad 91$

Table 2.29: Business Improvement District 92

Table 2.30: Quality/Availability of Groceries 94

Table 2.31: Quality/Availability of Restaurants or Cafes 95

Table 2.32: Quality/Availability of Shopping 95

Table 2.33: Quality/Availability of Downtown Housing 96

Table 2.34: Quality/Availability of Public Transportation 97

Table 2.35: Quality/Availability of Schools 97

Table 2.36: Quality/Availability of Colleges and Universities 98

Table 2.37: Quality/Availability of Health Care 98

Table 2.38: Arts and Cultural Opportunities 99

Table 2.39: Pedestrian Safety 99 
Table 2.40: Safety from Crime 100

Table 2.41: Employment Opportunities 100

Table 2.42: Tolerance of Diversity 101

Table 2.43: Attractiveness of Downtown 101

Table 2.44: Parking 102

Table 2.45: Quality/Availability of Parks and Greenspace 102

Table 2.46: Quality/Availability of Hotels 103

Table 2.47: Availability of Government Services 103

Table 2.48: Usage of Downtown during Non-Standard Business Hours 104

Table 2.49: Ability to Compete with Shopping Outside Downtown 104

Table 2.50: Support for Downtown from State Government 105

Table 2.51: Cross Tabulation of State Support and Grants Received 105

Table 2.52: Support for Downtown from Federal Government 106

Table 2.53: Cross-Tabulation of Federal Support and Grants Received 106

Table 2.54: Future Direction of Downtown 107

Table 2.55: Cross-Tabulation of Downtown and Future Direction 108

Table 2.56: Biggest Challenge Facing Downtown Development 108

Table 2.57: Raising a Family Downtown 109

Table 3.1: Ordinal Regression of Self-Assessment of Downtown 115

Table 3.2: OLS Regression of Self-Assessment of Downtown 116

Table 3.3: Regression of Self-Assessment without family variable $\quad 121$

Table 3.4: Quality of Life Correlations with Downtown Assessments 123

Table 3.5: Regression Model of Overall Downtown with QoL 125

Table 3.6: Regression Model of Direction Downtown is Heading 127

Table 3.7: Regression Model of Self-Assessment with Grants 129

Table 3.8: Regression Model of Self-Assessment with Policy Index 131

Table 3.9: Regression Model of Self-Assessment with Program Index 132

Table 3.10: Regression Model of Self-Assessment with Programs 133

Table 3.11: Regression Model of Self-Assessment with both Indexes 134 


\section{List of Figures}

Figure 1.1 - Diagram of a Successful Downtown 


\section{Chapter 1: Introduction to Downtown Development Policy}

\section{Downtown Development - A Policy Issue}

Downtowns are extremely important to small cities. They provide the majority of a small community's tax base (Robertson 1999). Downtowns are the site for major public investments, both currently and historically. The oldest and most recognized areas of a town are almost always in downtown, making it the embodiment of a city's heritage. These districts are also the traditional setting for cultural events and could be considered the social capital center of small cities (Robertson 1999).

Over $30 \%$ of Americans live in downtowns across the United States (U.S. Census Bureau). That alone, not to mention the business presence located in city centers, makes revitalization a policy issue not only for local policymakers, but also for state and federal levels of government. Downtowns promise to create millions of dollars in revenue for cities if they do become vibrant. (Johnson 2008). The Initiative for a Competitive Inner City (founded by Michael Porter) showed evidence that there was over $\$ 40$ billion dollars in unmet retail opportunities in 100 city centers across the country (Johnson 2008). To understand the costs and importance of these efforts and how they are intertwined with public policy, one can take a look at the "Fifth and Forbes" downtown redevelopment strategy undertaken by the city of Pittsburgh. Total costs were originally estimated to be $\$ 355$ million of which at least $\$ 52$ million 
were promised from the city (Development and Revitalization of the Fifth and Forbes Area Plan 2002). Remembering that this is only one of many downtown revitalization projects undertaken by Pittsburgh, the immense public costs and importance of the project should be evident, even if one does not take into consideration job growth (temporary and long-term), potential tax profits, and externalities (positive and negative).

Smaller cities also spend significant portions of funding on viability projects. For example, the city of Picayune, Mississippi (population approximately 11,600 ) in February 2009 allocated over $\$ 2.7$ million dollars in grant funding to their "Downtown Revitalization Project" (Pittari 2009). As another example, Morgantown, West Virginia has spent over three million dollars on streetscape renovations in its downtown with another five million promised from outside funding to further their efforts. For the 2009 budget year, the city allocated $\$ 534,000$ for public transportation, bike lanes, and traffic calming for pedestrians, $\$ 1.3$ million in parks, $\$ 520,000$ for improving a downtown riverfront center, and $\$ 342,000$ for a downtown theater (Morgantown City Budget 2009). While obviously all of the transportation, biking, and park money will not go to only the downtown district, a significant portion of it will, and the numbers show the vast amount of resources spent by small cities and towns on downtown revitalization.

All of these reasons make maintaining and developing a strong downtown crucial and demonstrate its importance to policymakers and Americans in 
general. Folz and French (2005) found that among mayors and city managers, downtown development was the \#2 issue mentioned, behind roads and bridges (which could also arguably contribute to the success of downtown). These observations about costs, benefits, and the importance of downtown revitalization to policymakers should also indicate why it is such an important subject for students of public policy to examine.

In recent years, growing attention has been focused on urban revitalization efforts. Unfortunately, students of public policy and political science have not thoroughly examined the government role behind this redevelopment, especially in an empirical fashion (Farst 2003). The research that has been conducted has focused largely on higher population metropolitan areas and rarely on smaller cities and communities. For one reason or another, small cities (roughly defined as having a population between 25,000 and 100,000 since geographers do not have an official definition of such) have very little scholarly research informing their downtown development efforts and outcomes. It should be noted that this population range would include many places considered suburban and not necessarily small cities. In the next chapter, a method for dealing with this discrepancy will be discussed. The following discussion includes an overall assessment of downtown literature and an exploration of how applicable this research might be to small cities. 


\section{Literature}

The literature about community development and downtowns can be divided into three main categories: Programs and Policies, Coalitions, and Quality of Life. Programs can include non-profit groups such as Main Street USA, historical societies that are active downtown, and government programs such as those that focus on housing and residential areas. Policies can include subsidies, tax increment financing districts, zoning regulations, business improvement districts, use of eminent domain by local governments, and other tools governments (federal, state, and local) use to maintain and improve their central business districts.

Coalitions involve how well major stakeholders, including public officials and elected leaders, local business, non-profit groups, and the general public work together to solve issues in their cities and maintain healthy downtowns. Quality of life includes not only the necessities of life such as water, food, clothing, and medical care, but also the availability of arts and culture, leisure activities, shopping, walkable neighborhoods, social capital, and other important elements of human society.

Of course, within the literature, there can be a great deal of overlap between these categories. They by no means have clearly defined boundaries or division lines. Instead, the categories point to what downtown "success" and "failure" really are. Programs and policies, quality of life, and coalitions all are essential to healthy downtowns, and all the research clearly points to these as 
being the three primary areas related to development and maintenance of healthy cities.

When small cities are the focus of analysis, it must again be noted that the vast majority of the literature focuses on larger metropolitan areas and major cities. That not only points out the serious need for a closer examination of smaller locations, but it also creates problems for generalization. There are many differences between large and small cities that must be understood including those found in Table 1.1.

\section{Table 1.1}

\section{Important Differences Between Small and Large Cities}

1. Small cities are more human in scale. People can walk entire lengths of downtown. Skyscrapers don't dominate the scene.

2. Small cities are not generally plagued with traffic problems or fear of crime.

3. Larger cities are dominated by a corporate presence in physical structures and economic influence.

4. Small downtowns often lack the large signature projects that are key components in large city redevelopment efforts.

5. Retail structure is different.

6. Downtowns of most small cities are not divided up into districts.

7. Many small city downtowns are closely linked to nearby residential neighborhoods within easy walking distance.

8. Small city downtowns are more likely to possess a higher percentage of historic buildings than large cities.

Source: Burayidi 2001 
One final note important to any introduction of downtown revitalization literature should be that much of the work, especially from the field of business and economics, focuses on the economic indicators of cities. "Success" is often defined by unemployment, poverty, income, and business revenues. The overall picture of the literature indicates that this view might be too limited and not accurately capture what policymakers, the public, and other experts think about as a "successful" city. Instead, economic elements are only a small part of a much broader picture that includes quality of life variables that make cities "livable". Indeed, one study examined perceptions of "successful" cities, as defined by policymakers and revitalization experts, and found that economic performance had no significant impact on which cities they considered successfully revitalized (Wolman, et. al. 1994).

In the sections below, each of these areas will be briefly described and then the literature examined in great detail in order to develop strong hypotheses about how downtowns live, grow, and sometimes decline.

\section{Programs and Policies}

Although there can be considerable overlap between these three areas of research, perhaps the single largest body of literature on downtown development focuses on programs that operate within cities to improve and maintain their central business districts and government policies that have been implemented 
within them. There are several main forms of program and policy discussion, which will be mentioned first here and then discussed at length later in this section.

First are general historical narratives of downtown development and revitalization since the turn of the century. These histories discuss how programs and policies have shaped the rise, growth, decline, or stability of cities across the United States, especially major metropolitan areas. Some of these focus on wider issues such as American culture, transportation policy, or housing and urban development while others simply look at the causes of decline and collapse among so many downtowns during the $20^{\text {th }}$ Century. These can be extremely useful in determining the most common and widely utilized programs and policies that have been implemented by cities over the last 100 years, as well as pointing in the way of possible hypotheses concerning the relationship of programs and policies to overall downtown stability. Unfortunately, the generality of this literature mostly lends itself to looking at major cities with large populations. That prevents the ideas presented there from being highly generalizable to smaller cities.

Next, there are case studies of one or more cities or towns, breaking down their individual stories, achievements and failures over a set period of time. Sometimes these are collected into books and presented together, tying them into generalized propositions, but other times they are journal articles that break down a specific city on its own with no context. Sometimes these have historical 
narratives of an individual case included in the discussion, but they can also just look at the basic status of a city (successful or failing) and try to understand what programs and policies might have led to this situation. Because this style of writing about cities often contrasts between successful and unsuccessful cities, it helps hypothesize the difference between successful and unsuccessful programs and policies and can lead to strong hypotheses as well. Again, the vast majority of case studies focus on major cities or at least larger geographical areas with populations over 100,000 although, as discussed in detail below, a few excellent studies focus on small cities.

It is also important to note that a considerable amount of survey research exists amongst this sub category of programs and policies literature. The specifics of each survey will be discussed in a separate section, but briefly it should be mentioned that these survey instruments generally fall prey to the same critique. While they assess feelings and ideas about programs and policies, the survey research makes no systematic effort to understand specifically what government efforts are in place in each community nor of how these might be contributing to the downtown.

The third major subcategory of program and policy literature includes many detailed examinations of specific programs and policies, such as Main Street USA program, housing policy, zoning, and tax increment financing districts. Some of these also focus on more niche ideas for successful downtown development such as antique shopping districts and sporting events. 
Within this area of programs and policy literature, we find the most in depth and quality discussion of small towns and cities. This is largely due to the fact that many programs, such as Main Street USA, often target small cities for their work (Smith, et. al. 1996).

Historical Narratives

Over the last century, while some downtowns have been able to successfully weather hard times and competition (perhaps have even continued to improve their downtown), many communities across the United States including some of the largest have suffered and started on a decline (Fogelson 2001). One prime example that is often discussed in the news, literature, and general conversation is Detroit, Michigan. Many written histories have focused on this decline, and they can provide pertinent information as to what caused the decline of these downtowns in the first place, as well as looking at the revitalization efforts of some downtowns which went through the decline, but have new life today thanks to decisions made regarding community development. Understanding both the causes and solutions of decline is essential to developing theory about city center success.

Policy decisions at all levels of government are usually thought to be responsible for the initial tailspin of downtown areas and, interestingly enough, most scholars expect government to be the one to restore cities to their former prestige as well. Various policies such as housing subsidies for veterans, increased funding to the Interstate Highway System, the lack of government 
spending in downtown neighborhoods, and other local, state, and federal government decisions led to a mass exodus from downtown areas both by citizens (at least those middle and upper class society members who were wealthy enough to afford escaping city centers), and by business owners who sought to tap into the resources of this fleeing middle class (Jackson 1885, Duany et. al. 2001) Of course, crime rates, poor educational systems, and urban rioting (Isenberg 2004) - all of which may have been a partial result of wealth leaving the cities - also contributed to this downturn. (Gutfreund 2004, Jackson 1985, Duany et. al. 2001, and Mattson 2002). Jackson (1985) gives a good example of such a historical study of downtown decline. He argues that federal government policy choices changed how property was arranged and owned and helped build the suburban layout of the United States that exists today. Specifically, the U.S. government after World War II structured taxes to be at lower rates on new construction and used the Federal Highway Act to emphasize and benefit road building projects away from city centers. The Federal Housing Administration hastened the decay of innercity neighborhoods by favoring single-family homes and discouraging multifamily projects. They also cut back on government loans for repair projects which also lead to the building of more single-family homes, an effort that proved to be much more affordable outside of cities where taxes and property prices were lower (See also Burayidi 2001). 
Combined with an unprecedented demand for housing at the end of World War II along with segregation between whites and blacks in the United States, the result of these policies was a suburbia that was said to be free of the problems of race, crime, and poverty. Many cities, and especially downtowns, began to go into major decline at about this time. This decline became so great that by the 1970s many researchers were calling for some control on the growth of areas outside of central business districts (Gutfreund 2004).

Also attenuating this problem was the rise in spending on cars, new travel patterns, a decline in the use of public transportation, and a decline in taxes after World War II. Because gasoline has historically been cheaper in the United States, we also have a false sense of the costs of suburban sprawl as well, which has led to its accentuation (Duany et. al. 2001). Brueckner (2000) notes that a growing population, rising incomes, and falling commuting costs (or at least commuting costs do not keep up with the rate of inflation) will naturally lead to a growth in suburban areas. He argues, however, that three market failures distort and exaggerate suburban growth. These are a failure to account for the benefits of open spaces (such as farmland that is turned into suburban development), a failure to account for the social and environmental costs of congestion and traffic caused by excessive commuting, and failure to make new development pay for the infrastructure costs that they actually generate (which could be seen as an indirect subsidy). 
Kottis and Kottis (1972) used statistical analysis to examine problems and solutions in downtown areas, specifically from a business perspective. Obviously, as people moved out of the cities, sales went down and some companies moved out of city centers or went out of business. The authors argued that in order to boost business downtown, policies must be implemented that restrict the growth of the city outside its core and keep people living in the downtown area. These ideas come to play in two ways. First, mixed use zoning keeps individuals downtown by allowing them to live, work, shop, and participate in other activities in city centers without having to travel elsewhere. Secondly, urban growth boundaries and urban service boundaries that restrict growth outside city centers and prevent cities from providing public services to those who do not follow these regulations help to boost cities.

By the 1950s, city revitalization started becoming a bigger issue to policymakers. Early efforts focused on making downtowns cultural centers, but unfortunately ignored another part of the picture - what was life like for those who actually lived downtown? After the mass exodus had begun of those with spending power, the situation was actually fairly grim. Urban renewal projects demolished neighborhoods where minorities lived, and many cities quickly became "alive" only between 9 A.M. and 5 P.M. (Frieden and Sagalyn 1991). Population density dropped in many cities, small and large. As these shifts occurred, distances between activities increased, making downtowns less pedestrian friendly. Sidewalks narrowed, walking became more dangerous from 
heavy traffic (moving in and out of areas outside the central business district) an increase in crime (Burayidi 2001). It became clear that something had to change in order for cities to survive.

Friedman (1973) took an interesting look at central business district retail activity in the largest U.S. cities from 1954-1967. He noted that, by 1973 , shopping centers were really starting to emerge in the suburbs, and only cities that were isolated and had steady populations living downtown were able to sustain business. Those who had lost significant numbers of residents to surrounding suburban areas were losing to competition from business on the fringe.

During the latter half of the $20^{\text {th }}$ century, the decline of heavy industry, mining, and manufacturing across the United States also contributed some to the decline of cities, especially some small cities that relied on one or two plants in order to generate income for the entire community. Some believe the deregulation of banking, transportation, and communication made the cost of doing business higher, while others believe pure competition forced out inefficient business (Johnson 2008). Regardless of which viewpoint is correct, the decline of these production oriented businesses did have a negative impact on the sustainability of many smaller communities during the last half of the 1900s (Mayer in Kemp, 2000).

Many cities turned to ideas such as downtown shopping malls (malls outside in suburban neighborhoods were often blamed for the failure of business 
in downtowns), pedestrian plazas, and other projects that were to be funded by the city. Because so much of the tax base was no longer around, however, funding of such projects by local government became a major issue. It is also unclear how successful some of these efforts have been, especially because of the lack of empirical evidence and the difficulties in assessing the true impact these projects might have on small cities and downtowns (Frieden and Sagylyn, 1991).

Richard Bingham (in Pelissero, 2003) provides another good summary of the last 25 years of urban development efforts, his work focusing on federal government city revitalization efforts. In the late 1970s, Jimmy Carter used "Urban Development Action Grants" that targeted needy communities using direct capital subsidies. These grants funded 3000 projects in 1200 cities nearly $\$ 4.6$ billion over the course of 12 years and were thought by experts of city development to have been fairly successful. Ronald Reagan supported the use of Enterprise Zones in communities, but did not think the federal government should fund these efforts. Only under the Clinton Administration did empowerment zones and enterprise communities come directly from the national level. All these efforts can be difficult to evaluate because so many other development programs, public and private, ran subsequently with them. In recent years, Tax increment financing districts (or TIFs) have become the preferred tool of government and have been heavily implemented in almost every state in the country. The jury is still out on their success as well, especially 
considering many of these are scheduled for a set amount of time (such as ten years) and have not come to completion yet.

Finally it is worth mentioning that there has been a rise in "big-box" retailing outside of city centers over the last few decades. Much has been written about the possible "Wal-Mart" affect on downtowns, and while the majority of analysis supports the idea that large retailers centered outside the urban core damage central business districts, there have been mixed results in such research (Sobel and Dean 2007), especially considering the difficulty of examining the real costs, including externalities and indirect costs, of this type of retail development and sales. For example, Fernandez (2004) demonstrates that the Wal-Mart corporation alone received more than one billion dollars in local and state subsidies between 1984 and 2004. At the very least, this research makes it important to examine the role of competition within the scope of downtown success.

Porter (1995) made an argument that inner cities actually held a competitive advantage over other areas such as suburbs and rural communities. One reason for this is accessibility to transportation and ease of export for cities. Using the example of seafood, for instance, a city on the coast has access to bringing in fish, shipping it out via interstate, rail, and air, and the population to sustain the sales and shipping operations. Using a more libertarian argument closely akin to some discussions of zoning, he argues that government may 
actually hamper some of the success cities would naturally have by regulating business and focusing on the wrong issues at times.

Perhaps one of the more interesting factors to consider when looking at the decline of downtowns and the mass exodus of middle class individuals into the suburbs is the perceptions that were created among the general public about city centers. Early in the $20^{\text {th }}$ century, downtown was seen as a place of culture, wealth, entertainment, and success. This viewpoint seems to have slowly eroded in the years following World War II and in the wake of the policy and cultural changes that took place then. Today, even after decades of revitalization efforts, many residents of the suburbs today still see downtown as "inconvenient, obsolete, and even dangerous" (Robertson 1995). This perception factor hinders individuals from embracing the opportunities presented by city centers and may need to be overcome in ways that will be discussed further under "quality of life" such as visioning, recruiting creative individuals back into downtowns, or other novel approaches that might shed a positive light on central business districts. This hurdle might be the first in truly revitalizing downtowns and restoring them to the important status they once held.

The general pattern we see examined in the literature, then, is one of decline after World War II, an awakening to the problem during the 1950s, continued decline because of manufacturing and industry through the second half of the $20^{\text {th }}$ century, and perhaps a renaissance in some cities thanks to mixed-use zoning and new development programs and policies towards the end 
of the 1990 s and early 2000 s. Indeed, current research indicates that the majority of large cities are actually growing in population living downtown (Birch 2002). Of course, some cities have escaped the decline, but those are mostly discussed in case studies, and not in the grand historical narratives of downtown health (Walzer and Kline 2001).

\section{Case Studies}

On of the richest sources of information about small cities comes from the wealth of case studies available in the literature. Through these studies, it is possible to pinpoint efforts by a diverse group of municipalities around the country to maintain or improve their downtowns. While case studies can always raise questions about generalization, they do give a nice index of many of the most popular policies and programs in utilized by government to enhance downtowns today.

Perhaps one of the most prominent and extensive case study collections about small towns is "Downtowns: Revitalizing the Centers of Small Urban Communities", compiled by Michael Burayidi (2001). It collects case studies from around the United States and from various scholars, specifically citing the lack of research on small cities and calling for future research in the area. Chapter 4, written by Burayidi himself, examines Appleton, Fond du lac, Green Bay, Oshkosh, and Sheboygan Wisconsin. All three of these towns underwent significant revitalization efforts after an initiative by the Wisconsin Downtown Action Council and the Wisconsin Main Street program (affiliated with Main 
Street USA). All five of these cities had gone into a decline largely thought to be caused by a combination of interstates and highways bypassing the city and the inability for downtown to compete with "big-box retailers" and shopping malls. Since malls and retail stores outside city centers drew business away from downtown, and the road system bypassed them and directed people away and towards outside shopping, restaurants, and entertainment, both of these problems seem rooted in economics. Offices such as those of lawyers, doctors, and other professionals also soon began locating outside the city as well. The stories of these five Wisconsin cities largely mimic what was discussed in the historical narratives, only on a smaller scale.

Using a combination of several policies and programs, largely implemented by local and state government, all of these downtowns went through a revitalization process. They used Tax-increment financing districts, business improvement districts, main street programs, rezoning efforts, and special events (such as a weekly farmer's market in the case of two of the cities) to try and draw individuals and business back to downtown. At this point, Burayidi finds a real barrier to examining the success or failure of these efforts. He readily admits that the problem comes at the evaluation stage of his research. Cities have not found hard evidence to show that revitalization efforts are making a difference in their communities. He quickly points out that further methods of investigating downtowns in small cities have to be created and implemented by students of urban studies. As with this example, other case studies collected in 
"Downtowns: Revitalizing the Centers of Small Urban Communities" discuss the importance of historical societies, competition with business outside the city center, and cooperation with key stakeholders in the community (Burayidi 2001).

Frieden and Sagalyn (1991) also produced a work including several important discussions. It focuses on five case studies: Feneuil Hall in Boston, Massachussetts, Pike Place Market in Seattle, Washington, Town Square in St. Paul Minnesota, "Plaza" in Pasadena, California, Horton Plaza in San Diego, California, and Suburban University Town Centre outside San Diego, California (as a control case study of a suburban "town center"). They specifically examine the use of these retail developments as competition for suburban shopping malls. Again, competition between businesses shows up as an important element of downtown development. This shopping center focused approach will be discussed in the next subsection in more detail.

A case study of St. Albans, West Virginia showed the city using a combination of public and private partnerships and special events, festivals, and parades to try and revitalize its community. It has been hailed as at least a limited success (Hechesky 2005). Urban growth boundaries (UGBs) were used in Portland, Oregon, and a case study comparing that city to Atlanta, Georgia found many benefits such as a decline in water usage and power consumption as a result. Atlanta had no UGBs or USBs and has had several problems arise as a consequence (Wagner, et. al 1995). 
Kalamazoo, Michigan (population approximately 80,000 ) suffered many of the same problems that have been discussed about the decline of other cities above. Around 1959, they began a program of using private money to fund sidewalk and lighting projects to improve the safety and perception of downtown. Because they were able to limit relocation of retail business during the implementation of the project, it is thought to have increased profits and spurred new development (Sanders 1987). Pittsburgh, Pennsylvania found a series of apparent successes by bringing together important elected officials, business leaders, and the general public, which again points to the necessity of strong coalitions between stakeholders in any revitalization effort (Crowley 2005, Friedn and Sagalyn 1991).

Faulk (2006) attempted to gauge "secondary cities", or what might be considered neighborhoods, within large metropolitan areas. He used population change, the number and quality of housing, and income data from the U.S. Bureau of the Census to try to gauge the direction different neighborhoods have taken.

One good way to give an overall summary of case study literature is to describe a comprehensive look at Elkins, West Virginia (Sakamoto 1995). It helps illustrate many of the apparent problems and solutions that small towns develop over time. Elkins was built on the coal and railroad industries and became an important wholesale center for distributing goods throughout the United States. In fact, from the late 1800s until the mid-1900s, Elkins had been a 
booming and highly successful city, with the downtown as the center of attention. In the 1940s through the 1960s, however, mining and timber began a long decline and the city had to try to become more dependent on recreational tourism and income generated by their collegiate level educational institution, Davis and Elkins College.

In the 1970 s, the railroad companies completely ceased operations in Elkins. Staggering numbers of the population moved away, and downtown was left stagnate. Like many other towns, the lack of funding became an issue and the city decided to give up on many of its revitalization efforts. New businesses such as big-box retailers who required more physical space began opening up in strip malls miles from downtown. New roads funneled residents and visitors alike outside the central business district for their shopping needs. Buildings began to deteriorate creating blight and a perception of danger. Business owners downtown became apathetic (Sakamoto 1995).

A survey Sakamoto conducts also shows that citizen perceptions became a key player in the decline of downtown as well. Higher income individuals began to see living and shopping downtown as something only for low income people. Elkins needed change, and in order to pursue revitalization, they, as many other cities do, turned to the Main Street USA program. Main Street seems to have been successful in changing people's attitudes in some ways, and although individuals still preferred chains for their wider variety of goods and bigger parking lots (easier access), there was a slight rise in respect and sales 
for business in downtown Elkins (Sakamoto 1995).

Specific Policies and Programs

Policymakers have an extensive number of policy measures at their disposal and additionally, a wide variety of non-profit and federal, state, and local government sponsored programs meant to supplement the growth of communities. For example, Bengsten, et. al. (2004) attempted to compile an inclusive list of policy measures at the disposal of cities to manage urban growth as seen in Table 1.2 below. 
Table 1.2

Policy Tools to Manage Urban Growth

- Public Acquisition

- Public Ownership of parks, recreation areas, forests, and other natural resources

- Protection of environmentally sensitive areas

- Development moratoria

- Interim development regulations

- Ability to set a rate of growth/growth phasing regulations

- Adequate public facility ordinances

- Upzoning or small lot zoning

- Minimum density zoning

- Greenbelts

- Urban Growth Boundaries

- Urban Service Boundaries

- Planning Mandates

- Business Incentives for clustered growth

- Development Impact Fees

- Development Impact taxes

- Real estate transfer taxes

- Infill and redevelopment incentives

- Split-rate property taxes

- Brownfields redevelopment

- Location efficient mortgages

- Historic rehabilitation tax credits

- Subdivision exactions

- Cluster Zoning

- Downzoning or large-lot zoning

- Exclusive agricultural or forestry zoning

- Mitigation ordinances and banking

- Nontransitional zoning

- Concentrating rural development

- Right to farm laws

- Agricultural districts

- Transfer of development rights

- Purchase of development rights

- Conservation easemnts

- Use-value tax assessments

- User Fees

- Circuit breaker tax relief credits 
- Capital gains tax on land sales

While obviously all of these policies are not explicitly applicable to downtown redevelopment and there are a wide variety of downtown specific tools that are not mentioned here, it does serve as an introduction to the wealth of options communities have to deal with sprawl and growth beyond the central business district. The literature treats these and many other public policies and programs in great detail, and it is worth taking some time to make a detailed examination of scholarly research on some specific programs and policies that have been discussed most frequently within urban development policy analysis efforts.

One of the most important policies affecting the life of downtowns is zoning law. Most cities have the ability to allow different types of development within the central business district. Some allow business, industry, residential neighborhoods, and retail to exist side by side, where people can live, work, shop, and play downtown. Others are more restrictive, perhaps limiting the amount of city blocks where people can live or zoning specific areas for one purpose exclusive of the others (Daniels 1995, Levine 2005).

Perhaps surprisingly, there is a large amount of agreement that mixed-use zoning has a positive impact on communities and increases the vitality of downtown (Florida 2003, Levine 2005, Burayidi 2001, Daniels 1995, and Robertson 1995). Although some advocates of free-market capitalism have argued that the death of downtowns and growth of areas outside the city core 
are the natural result of market forces, Levine (2005) offers an interesting look at this theory, and even argues that the rise of zoning law (restricting the use of downtown neighborhoods) was actually government interference in the market and created some of the problems that caused the decline of cities in the first place. He argues that zoning artificially inhibits a city from natural growth and a booming downtown, and that American cities have literally "zoned out" residents and others who would take advantage of what cities offer.

Tax Increment Financing Districts (TIFs) are the most commonly used tool reported to be in use by local policymakers in 2001 (Walzer and Kline 2001). Generally intended to be used only in "blighted" areas around the city center, tax increment financing districts generally allow a deferment of local property taxes that are meant to go back into the development of the blighted area. It is expected that the property values in this area will go up, and the city will eventually recoup lost tax revenues along with making a profit from higher property taxes in the long term (perhaps 20 or more years in the future).

Because of their extended lifetime, and the fact that TIFs really started coming into existence in the 1970s in California and have only more recently spread to almost every state in the U.S., it is hard to determine their impact on local communities at this time (Burayidi 2010). There is a lot of room for mistakes (for instance if a project fails to generate higher property values over the long term), and these districts have often come under fire when perceived as public funding for private development (Pelissero 2003). 
Strategic planning or "visioning" is also a common tool used by communities to bring policymakers, business leaders, residents, and non-profit groups together and make long term goals. Using this method, cities bring together stakeholders and discuss what needs to be done to improve or maintain a city. A long term plan for the city is drawn up, with the intention that those who participated in the visioning process will be drawn into the development efforts and work towards a successful implementation of the plan. Visioning comes as highly recommended by many policy experts and is often touted as an essential step in downtown revitalization (Flora 2003, Leinberger 2005, Burayidi 2000, and Robertson 2006).

Business improvement districts (BIDs) are a defined area of a city where properties and businesses are given an extra tax or fee on that goes back into the neighborhood. The revenue generated is generally turned over to a Business improvement district organization, created by the city for this specific purpose, who are to use the money to do whatever seems appropriate to increase the appeal and overall sustainability of the given area. In 2001, there were 404 Business Improvement Districts in the United States, and a survey showed that their governing organizations were mostly involved with marketing downtown, street and sidewalk cleaning, crime control, and being an advocate with local government on behalf of those who lived and operated within the district. Little research has been done to assess their success or failure (Mitchell 
2001).

Much has been written about "smart growth" policies. Smart growth includes a variety of ideas about how cities should be structured and rests on the assumption that sprawl has a negative impact on communities. Handy (2005) describes these specific propositions made by proponents of smart growth regarding transportation:

- Building more highways will contribute to more sprawl

- Building more highways leads to more driving

- $\quad$ investing in light rail transit systems will increase city density

- adopting "New Urbanism" design strategies will reduce automobile use Some cities and states have directly targeted these ideas and tried to use transportation related smart-growth principles in their design. Handy's analysis finds some mixed conclusions about the efficacy of these policies, specifically that:

- New highway capacity does indeed influence where growth occurs.

- New highway capacity may increase traffic slightly, and it is evident that at the very least it does not reduce traffic or congestion over an extended period.

- These strategies do make it easier for those who want to drive less to do so. 
- Light rail systems encourage higher density, but only when:

- the region is experiencing significant growth

- the system adds significantly to the accessibility of the locations it serves

- stations are located in areas where the surrounding land uses are conducive to development

- public sector involvement in the form of supportive land use policies and capital investments exists

Perhaps the more common tools policymakers use related to smart growth are urban growth boundaries (UGBs) and urban service boundaries (USBs). Urban growth boundaries limit where development can occur within a geographic area. Generally, they serve to funnel development into more densely populated areas and prevent large and unchecked growth of sprawl on the city's fringe. Urban service boundaries serve much of the same purpose, but they specifically lay out exactly where public works projects and services will be provided to new development and any projects outside that boundary do not receive them. For example, a development project that took place outside a USB might not receive free or subsidized public water lines, sewage systems, or garbage service from the municipality. Many times these programs are mandated by state legislatures and cities are expected to follow through using comprehensive planning, which is sometimes produced yearly and reviewed at 
the state level (Daniels 2001, Handy 2005, Brueckner 2000).

One of the earliest attempts at implementing this type of urban growth policy was started by the state of Hawaii in 1961. Their statewide planning program divided the state up into zones which restricted development in one way or another. Since 1973, the state of Oregon has worked with local governments in a similar manner. Each city and county is required to draw up urban growth boundaries to promote growth within the city with the goal of saving money on public services and protect forests and farmland. Washington State followed with the 1990 Growth Management Act (Daniels 2001).

Maryland has implemented a series of "Smart Growth" reforms coming down from the state government level. The state defined priority funding areas outside of which no funding will be available to assist in infrastructure development. Business owners within these boundaries were given a tax credit for job creation, the state purchased environmentally sensitive land, and Maryland created a "Live Near Your Work" program where people who purchased homes near their job were eligible for $\$ 3$ thousand dollars (Daniels 2001).

Attempts to evaluate these efforts have met with mixed success. One analysis of Maryland's program found that it was too early to examine its effects on containing growth (Daniels 2001). Some have found that UGBs that are poorly implemented or too stringent can lead to an inappropriate escalation in housing costs and unwarranted increases in the density of urban centers 
(Brueckner 2000 and Handy 2005). In a comparison of Atlanta, Georgia (who has no urban growth program) and Portland, Oregon, Wagner (1995) found that Portland has had considerable success and benefits from their urban growth policies.

Bengsten, et. al. (2004), citing the lack of empirical evaluations of growth management policies, found administrative efficiency and policy implementation as key to the effectiveness of smart growth strategies. When multiple policy instruments that complement each other were used, it helped negate unintended consequences of these urban growth control efforts. Finally, cooperation and stakeholder participation were key to effective and successful growth management policy.

Regarding the topic of the growth of urban sprawl, an element of public policy that cannot be ignored is the amount of subsidization (direct and indirect) that targets suburban neighborhoods and businesses. Besides subsidies that help give suburban big-box retailers an edge over downtown business (discussed later), other types of government policy have influenced the growth of suburbia and decline of city centers. One such example is tax credits for new construction (Duany, et. al. 2001). Such credits are generally more favorable than redevelopment opportunities and improvements to existing structures, such as those that exist in a downtown area, are not eligible. Indeed, a study of subsidization by the federal government found that the vast majority of subsidies benefit housing and business outside urban cores, which would tend to indicate 
a disadvantage to downtown (Persky, et. al. 2001).

Arguably, one of the most prominent programs used to revitalize downtowns in the United States is the Main Street USA organization. Main Street, created and administered by the National Trust for Historic Preservation in 1980, is located in hundreds of small cities across the United States and its main purpose is to foster strong downtowns, especially with regards to increasing the quality and success of local business. Using a combination of networking and cooperation between key business leaders, local government officials, non-profit groups, and the general public, they offer ideas and events to a community in an attempt to improve the perception of downtown and eventually improve the amount of business that goes on, including shopping, restaurants, nightlife, and cultural activities (Smith, et. al. 1996). Main Street seems to have been largely limited, although not exclusively, to communities who were unable to afford larger redevelopment tools such as downtown malls and other major investments (Robertson 1997).

Main Street sets up a non-profit organization in selected downtowns across the country. They work centered around a "Four Point Main Street Approach":

1. Organization - Fundraising, membership recruitment, public committee structure, and consensus building and cooperation among the many businesses, individuals, institutions, and government offices who have some stake in downtown. 
2. Design - Enhancement of downtown's physical qualities, visual assetts, and preservation of architectural design.

3. Promotion - Marketing downtown through the use of events and activities meant to bring the public into the city center and enhance the image individuals have of the central business district.

4. Economic Restructuring - Strengthening and diversifying the downtown's economic base with an emphasis on long-term gains. (Robertson 2006, Smith et. al. 1996)

Smith, et. al. (1996) presented an official look at downtown revitalization strategies from the Main Street perspective. With high regard to detail, this work discussed issues such as parking downtown, painting buildings, and conducting surveys of downtown customers to find out what they were looking for and how their needs were met. It gives a good general idea of what Main Street is about and how the organization operates in the local community.

Main Street has been heralded as a success by many researchers, demonstrating growth in communities that have an organization operating within its city limits, and allowing communities to have "better than average" economic conditions, even during recession periods (Sakamoto 1995, Loescher 2009, Smith et. al. 1996, Robertson 2006, and Hechesky 2005). Hechesky (2005) argues that Main Street is successful when the following factors are working in conjunction with the local organization: 
- City Support

- Private and Public Partnerships

- A Focal Point Downtown

- Promotions

- Events and Community Celebrations

What has not been done, however, are empirical studies to see if Main Street programs are the catalysts of success or if they choose communities to center themselves in that may actually be strong and growing in the first place. It remains unclear from the literature if Main Street USA would be as successful with other programs and policies controlled for in the analysis. Regardless, it remains one of the more popular and seemingly successful programs to aid communities and must be an important part of any research on small city downtown success (Smith 1996).

Historic preservation programs are also an important program that are implemented both by government and non-profit groups. By protecting areas and infrastructure that are thought to be historically significant, it is hoped that these efforts will enhance the overall image of a community and perhaps even draw in "heritage tourism" dollars to the city (Listokin, et. al. 1998). The use of these programs has met with mixed reaction. One one hand, it does seem to have brought in tourism and business dollars in many communities who have used it. On the other, some have begun to argue that historic preservation may 
protect market inefficient business, hamper new (and perhaps needed) development, and may displace area residents and harm housing production and improvements in downtown areas (Listokin, et. al. 1998). As with many other programs and policies, a lack of solid empirical evidence exists to determine which side of the debate is correct.

These are but a few of the many policies and programs at the disposal of small municipalities and other government levels in order to build and maintain strong downtowns. Other policies such as user fees, development moratoria, subsidies, and grants from state, federal, and non-profit groups are mentioned in passing, but never examined in detail. They seem to be frequent and important, however, to include in any summary of policy and program options. Each of the most commonly used policy tools will be defined in the next chapter as a methodology for testing their efficacy is unveiled.

\section{Quality of Life}

Perhaps the most nebulous of the three contributors to downtown vitality is quality of life. Going beyond the basic needs of food, clothing, and shelter, quality of life includes housing, shopping, schools, health care, diversity, employment, aesthetics, and more. In many ways, these issues can overlap with policies and programs. The decisions to put a shopping mall downtown or to repave sidewalks, for instance, incorporate a policy choice. Perhaps a program such as federal grant funding or Main Street was involved in such a decision, causing even more overlap. Also, quality of life issues involve cooperation and 
communication between key stakeholders. That makes them a slightly harder topic to discuss. Additionally speaking, quality of life issues may actually be the definition of a "successful community". After all, isn't a successful community one that has good shopping, walkability, healthcare, tolerance of diversity, and employment? Caution must be exercised in order to test hypotheses involving quality of life as an independent variable and downtown success as an dependent one.

Shopping and other forms of retail are probably the most common quality of life issue discussed in the literature. This is largely a function of the importance many studies put on business and tax revenue (See Sakamoto 1995). Indeed, it seems that many downtowns strive to be the center of shopping and blame competition from business outside the city center as the main reason for failure to succeed (Walzer and Kline 2001).

The term shopping can include retail stores, restaurants, groceries, and even hotels and will be used in a very general sense here, incorporating all types of customer centered business that goes on downtown. Improving shopping downtown is also one of the main functions of the Main Street USA program (Loescher 2009).

Because competition from business outside city boundaries is often seen as the primary cause of downtown decline, it should come as no surprise that many studies focus on downtown malls and other efforts cities implement to try and compete with that development, especially when no urban growth 
boundaries or urban service boundaries are present. From about the mid 1960s through the 1990s, the erection of downtown shopping malls was "a preferred instrument of downtown revitalization in mid-size urban areas" and was often used to combat competition from outside (Filion 2006).

This strategy may briefly have strengthened cities economically (Houston Jr. 1990), but in the long run seems to have been a failure. The downtown malls have largely been unable to compete successfully with competition from "big-box retailers", were heavily subsidized by taxpayer dollars, and along with other solutions that attempt to make downtowns more "suburban", the building of downtown malls has largely been abandoned by cities now (Frieden and Sagalyn 1991, Robertson 1997, and Filion 2006). In its place, current efforts are focusing on historical shopping districts and a traditional approach to shopping downtown (Filion 2006).

Another concern is that business within downtown does not only happen during daytime hours. A vibrant nightlife can strongly affect the success of mixed use zoning. After all, a dead downtown at night can be at least perceived to be more dangerous, less clean, and overall less desirable to live, work, or shop in. Individuals are more likely to spend time, live in, and have a higher satisfaction with downtown when business is not restricted between 9 AM and 5 PM (Leinberger 2005 and Frieden 1991) It can also be useful in recruiting more diverse and younger residents (Florida 2004).

Being able to live downtown by having quality, affordable, and safe 
housing can be important to downtown success (Florida 2004). This gives residents convenient access to work, restaurants, shopping, and other business in a city center and can extend the length downtown is conducting business and draw in considerable revenues for the city (Leinberger 2005). Partially, this can be accomplished through the use of zoning policy to allow mixed uses (Levine 2005).

Cities and non-profit organizations have frequently turned to sponsoring festivals and events as a way to improve their image and draw in tourists and residents to visit downtown. These events are designed to showcase local specialties and positive community traits, draw people physically into downtown, and hopefully improve not only the overall perception of central business districts, but also build lasting business revenue increases. Events such as "Farmer's Markets" can overlap with shopping as well. These events are being described as a success in many areas, especially because they can help incorporate others in discussion about revitalization efforts and improve misnomers about what downtown is actually like (Burayidi 2000 and Hechesky 2005).

Public transportation and pedestrian accessibility can be important to downtown success (Duany, et. al 2001). Transportation, such as light rails, can increase density in central business districts if stations are located properly, accessibility is not limited (such as by poor operating hours), and if there are already destinations to be reached (Handy 2005). Although parking can be an 
issue for downtowns to be successful, one needs to be careful not to overplay its importance, and let other perhaps more pressing concerns like pedestrian access suffer. Indeed, Shoup (1997) argues that a reduction in the amount of parking, the elimination of free parking, and the raising of meters and other sources of revenue from downtown parking can actually enhance the quality, density, walkability, and cultural value of downtowns, eventually making them more successful and sustainable.

Quality sidewalks and pedestrian access are definitely seen to be important parts of downtown development (Sanders 1987, Robertson 1995, and Burayidi 2000). This can be accentuated by issues such as attractiveness of downtown, open and green spaces, architecture, and the upkeep of historical buildings (Rypkema 2003, Smith 1996, and Hechesky 2005). Major institutions such as quality universities, schools, and employers can also serve as "anchors" on downtown (Duany et. al. 2000); places where individuals want or need to go on a regular basis and thus will spend more time in city centers, perhaps with some spillover effect (Maurrasse 2007). These anchors, especially when located close to walkable neighborhoods and quality infrastructure can also be a major contributor to a successful city (Farst 2003).

Pedestrian malls, where a roadway is removed and pedestrians can walk down the middle of the street, have been attempted in many cities. They have largely failed to spur retail development, but they have increased the amount and quality of open space in downtowns (Robertson 1995). Many of the pedestrian 
malls that were created have again been replaced with drivable roads. Some experts believe that pedestrian malls were removed prematurely before long term economic effects could be examined. It is also thought that part of the problem were that many of them were built too far away from the central business district to be of real help to downtown (Houston Jr. 1990). Skywalk systems seem to have been more successful as an economic stimulus strategy (Robertson 1995).

Quality housing is essential to a successful downtown. Not only does the housing increase the diversity and quantity of residents (Florida 2004 and 2007), but as a result spurs higher economic gains for business and tax revenues (Listokin et. al. 1998). Unfortunately, many of the policies of the mid1900s caused a decline in the quality and availability of housing and left many minority communities living in horrid conditions in many cities (Jackson 1985). Using policies such as tax credits, flexible business codes, and historic preservation, many communities are trying to improve these conditions currently, and the differences could be a major impact on downtowns (Listokin et. al 1998).

Art, music, sports, and other cultural points can also help shape downtown. When these "special activity generators" are downtown they may stimulate new construction and cause spillover business to nearby stores and restaurants (Robertson 1995) and help recruit the "creative class" (discussed more below) to cities (Florida 2004 and 2007). Massive building projects like sports stadiums, however, have extremely high costs and can be risky to cities 
involved and may even leave large areas of dead space if they are unsuccessful, although that mostly concerns large metropolitan areas (Curry et. al. 2004 and Robertson 1995).

A discussion of quality of life would not be complete without a brief discussion of one of the more current ways at looking at cities, the "Creative Class". Championed by Richard Florida (2004 and 2007), this philosophy argues that if cities can attract a certain type of people (young, diverse professionals who are interested in quality of life and including some artisans and musicians to provide cultural enhancement), then downtowns can be sustainable in the long term. His research touches on issues included in much of the quality of life discussion here such as housing, employment, cultural opportunities, and walkability. Florida also discusses the important issue of tolerance of diversity within cities (Florida 2007).

These ideas are not without their critics. Some believe that Florida's ideas rely more on making money as an adviser to cities than hard science (Peck 2005). Peck also argues that art and music cannot be artificially created and imposed in cities. Nevertheless, creative class literature offers some interesting ideas that are important to cities today and need to be examined in any detailed study of downtown success.

\section{Cooperation}

One key component that appears again and again in the literature 
discussed here is the importance of cooperation between key stakeholders in a community. These individuals can come from a variety of backgrounds, including but not limited to:

- Elected Officials and Local Government Employees

- State Government

- Federal Agencies

- Non-Profit Groups

- Residents of Downtown

- Residents of neighborhoods near downtown

- Local Business Leaders

- Developers

In discussing how rural communities adapt to modern challenges and dynamically solve problems confronting their decision makers, Flora (1997 and 2003) spends a good deal of time attempting to explain the importance of cooperation and consensus building among local officials. She explains that, quite often, entrenched elites who have substantial political capital and the backing of community members will oppose redevelopment projects that are thought to be highly beneficial to an area because of their fear of change and the desire to retain control of power. To counter this opposition, she suggests fostering cooperation through town meetings, introducing the entrenched elites to benefits they may not immediately see, and trying to involve them in decisions to 
aid communities.

This type of reaction against positive growth can have a tremendously negative impact on a rural community, and basically keep it from developing, solving problems that arise, and ultimately succeeding. Flora demonstrates, using case studies and multiple examples, how community leaders have been able to overcome these hurdles and create successful towns in rural areas simply by finding ways to incorporate all the stakeholders in the process. Once the entrenched elites are on board and cooperating, the results are very positive.

While, as mentioned, Flora focuses mostly on rural communities, the same ideas seem to apply to small cities and urban areas as well. Certain stakeholders can generally find ways to defeat positive growth and change when their opposition is significant. The literature attests to the importance of cooperation, and it could be expected that a key element in creating a successful downtown is to establish strong public-private partnerships (Burayidi 2001, Leinberger 2005 and Robertson 2006). Farst's (2003) survey of city managers showed that they believed coalitions to be one of the most important elements of successful communities.

One of the theoretical underpinnings of why coalitions matter ties in with ideas about a "strong democracy". Barber (2004) writes about the need for citizens to be involved in policy making to some degree, and how that creates a stronger and more vibrant democracy in the United States and elsewhere. While redevelopment usually isn't thought to fit in this sphere - it has largely been seen 
as something that is purely administrative and closed to the general public because of their lack of policy expertise - case studies have shown that residents not only can and want to be involved in downtown development, but that they actually seem to have a fairly capable knowledge of policy options and specifics. When coalitions of citizens, business owners, government, and developers work together and not individually, these open projects tend to be much more successful (Crowley 2005). And, perhaps they also create "strong democracy".

Perhaps one reason involvement of a plethora of groups is important is because when people begin to plan the design of downtown, they feel included in that process and begin to believe in the potential their city has. This inclusion causes them to feel a stake in what is happening and drives them to work towards success (McClure and Harand 2001). Another reason to look at coalitions is because they happen regardless of whether they are intended or not. Pelissero (2003) shows that in any given development project, at the very least some private business interests, special governments, state government, the city government and county government are generally involved. Even without residents and non-profit groups, cooperation is essential because of all the different levels of government involved. Perhaps the quality of the coalition is just as important as if one exists and how large it is.

One of the most commonly cited models of cooperation and its benefits is the "Pittsburgh Model". Basically, Pittsburgh successfully brought business 
leaders to the table and began to implement comprehensive revitalization programs with their support (Frieden and Sagalyn 1991). When citizens and residents became concerned with the "Marketplace at Forbes" development, the city had been making very little effort to involve them in the planning process. So, they began grassroots movements and became very successful in putting all the major stakeholders at the table together, which seemingly led to a stronger development plan that worked out well in the long term (Crowley 2005). From this it should be noted that even when coalitions are not perfectly formed at the beginning, an interested and determined populous or private interest can take the initiative to join revitalization efforts.

Revisiting the literature on specific policies and programs, we find that coalitions and consensus building can be key to the success or failure of specific efforts. Quality of life literature, especially about creative class and the need for new approaches to communities always espouses the importance of inclusion of a diverse group of people in both living downtown and being a part of its planning (Grisham 1999, Florida 2004 and 2007, and Johnson 2008). Main Street USA touts consensus building among key stakeholders as one of its most important functions and as the only known way to succeed (Hechesky 2005). Drawing up strategic plans and doing "visioning" involves cooperation and mass participation by its very nature. Even the legal centric smart-growth policies like urban growth boundaries and urban service boundaries claim that the only way to achieve success is to include "meaningful stakeholder participation throughout the 
planning process" (Bengsten, et. al. 2004).

In summary, coalitions and cooperation among everyone involved in downtown is essential to successful downtowns. It is an important element of policies, programs, and quality of life ideas. It can make or break the outcome of any downtown revitalization effort.

\section{Survey Research}

Walzer and Kline (2001) argue that the best and most complete assessment of downtown condition is a survey of policymakers. Because of that importance, several researchers have used survey instruments to understand what problems are faced and tools and solutions that policymakers are using in their communities to overcome these hurdles. Surveys have provided some of the most central empirical evidence we have of downtown redevelopment, but prior efforts also fall short when examined in light of evaluating the success or failure of efforts. Most are intended to get a sense of status instead evaluating the outcomes of policy and revitalization.

Farst (2003) provides one of the most comprehensive surveys of policymakers regarding downtown development. She surveyed a sample of 256 small city managers across the state of Texas. Citing a lack of empirical literature on downtown policy issues, she finds that policymakers believe a mixture of policies and programs (especially mixed-use zoning), cooperation among key stakeholders, and quality of life issues such as pedestrian friendly 
streets, architecture, and special events are all the most important aspects of downtown success.

This study is extremely important, because it demonstrates a match between practitioners' beliefs and literature regarding the important factors in downtown success. Farst does not take the additional step of examining what policies and programs are active in communities or if officials believe their town is successful in implementing these ideas.

Walzer and Kline (2001) surveyed local officials about the stability and prosperity of their downtowns. Respondents were asked directly what caused decline in their downtowns, and the number one response was "competition from neighboring large retail centers" - again focusing on the competition aspect of central business districts with business outside city cores. The most common policy tool implemented were tax increment financing districts. This study was similar to another that showed economic development as the major issue outside of infrastructure facing local communities (Folz and French 2005).

Two statewide surveys, "Progress in Pennsylvania Downtowns" (2004) and "The Vitality of West Virginia's Downtowns" (Hanham 2006) attempted to see what policymakers felt were serious problems in their downtown and how they felt about the direction their community was headed. Both had mixed results, but found respondents to be very optimistic about the future direction of their cities.

A survey targeting residents of a "hot" city (one that is thought to be 
successful at attracting and retaining the creative class) found that issues such as quality of life, race relations, street repairs, and political leadership were the most important influences on perceptions of city success. These findings illustrate that there is more than just economic viability to the quality of downtowns (Orr and West 2002).

A number of non-comprehensive and niche surveys have also been conducted regarding downtown development. One survey intercepted shoppers in Elkins, West Virginia in order to ask customer preference and perceptions of merchants (Sakamoto 1995). By doing so, the research was able to point out what types of goods and services residents wanted to purchase, where they were available, and what brought them to a specific area. Based on the survey results, four recommendations were made as to how to keep business downtown:

1. Costs: The state or city should provide public programs aimed at reducing the cost of doing business downtown.

2. Market: Increase the number of customers, this can be partially accomplished by the use of festivals and special events.

3. Personnel: If possible, provide retail and job training courses for downtown businesses. The "personal touch" of businesses in the city center was one of the major reasons customers were attracted to shopping downtown. 
4. Public Infrastructure and Services: repairing sidewalks, rights of way, streets, etc. and public service programs like arts, recreation, and cultural programs were key to the success of downtown business.

In 2009, Main Street US produced its "2009 National State of Main Street Report" (Loescher 2009), reporting the results of a survey they conducted. Because the United States economy was suffering from a slight recession at the time, they were interested to see how Main Street districts compared to major chains in the United States. Indeed, nearly half of all Main Street programs reported a drop in sales among business in their communities. The interesting finding, however, was that Main Street businesses had less steep declines than major chains.

A survey of business improvement districts (BIDs), discussed earlier, revealed the major role and immense responsibilities that these organizations served in communities (Mitchell 2001). West and Orr (2003) conducted a pilot study survey in Providence, Rhode Island to understand what effect a downtown mall had on shopping behavior, views on community spirit, and the mayor's job performance evaluations.

Finally of note was a national survey of 57 small towns in the United States in 1995, asking them to rank the biggest problems facing downtown and the biggest assets they felt the community possessed. The top three problems 
were:

1. Attracting new development

2. Attracting people downtown during evenings and weekends

3. Competition from other business

The question was not open-ended, however, so some these were the top three out of set choices (Robertson 1995). As for the best assets communities had, respondents chose the following as their top three:

1. Preservation/Architecture/History

2. Waterfront/Riverfront

3. Daytime workforce

While surveys that have been conducted add much to our understanding of what policies and programs are in place in communities, what problems and hurdles exist for downtown, and an idea of assets communities have to deal with them, no survey seems to have been a comprehensive look at what policies are implemented and how they seem to effect downtown. Most have small sample sizes and/or are not applicable to the nation as a whole. The specific relationships between all of these variables are rarely, if ever, examined in a systematic, empirical fashion.

\section{Possible Barriers}

It is useful to take a moment to examine the obstacles that the literature 
finds to be in the path of downtown success. Since the literature clearly illustrates the importance of quality of life issues, cooperation among key stakeholders, and programs and policies as important, we would expect that if any of those things was lacking it would provide a significant challenge to a city.

At the same time, the literature suggests that two other issues may be important to cities. First, competition from outside of downtown was not only rated as the third highest problem on a national survey (Robertson 1995) and the highest ranked contributor to decline on another (Walzer and Kline 2001) but has been examined in a number of other studies (Sobel and Dean 2007, Sakamoto 1995, Loescher 2009, Burayidi 2001, and Frieden and Sagalyn 1991). This competition obviously is thought to be a major factor in the decline of communities and potentially damaging to revitalization efforts. Second, research points to the importance of adequate financial funding for projects. Policymakers and respondents to surveys have consistently cited the lack of funding as a major barrier to a successful downtown (Frieden and Sagalyn 1991, Farst 2003, Sakamoto 1995, and Pelissero 2003).

\section{Conclusion of Literature}

What we can conclude then, from the literature, is that programs and policies, cooperation and coalitions, and quality of life all affect downtown quality and revitalization. Table 1.3 summarizes some of these ideas: 
Table 1.3

Elements of the Literature

\begin{tabular}{|c|c|c|}
\hline Policies and Programs & Quality of Life & Coalitions \\
\hline $\begin{array}{l}\text { - Zoning } \\
\text { - TIFs } \\
\text { - Tax Abatements } \\
\text { - User and } \\
\text { Developer Fees } \\
\text { - } \text { Tax Credits } \\
\text { - } \text { Main Street } \\
\text { - } \text { Erogram } \\
\text { - Govinent Domain } \\
\text { - } \text { Grants } \\
\text { - Historical Societies } \\
\text { - Subsidies } \\
\text { - Urban Growth and } \\
\text { Service } \\
\text { - Boundaries } \\
\text { Business } \\
\text { Improvement } \\
\text { Districts }\end{array}$ & $\begin{array}{ll}\text { - } & \text { Festivals and } \\
\text { - } & \text { Shents } \\
\text { - } & \text { Housing } \\
\text { - } & \text { Public } \\
& \text { Transportation } \\
\text { - Anchor Institutions } \\
\text { - Health Care } \\
\text { - Arts and Cultural } \\
\text { - Opportunities } \\
\text { - Sedestrianization } \\
\text { - Eafety from Crime } \\
\text { - } \text { Diversity } \\
\text { - Aesthetics } \\
\text { - Open/Green } \\
\text { - } \text { Space } \\
\text { - Narking } \\
\text { Nightlife }\end{array}$ & $\begin{array}{l}\text { Cooperation between key } \\
\text { stakeholders including: } \\
\text { - } \text { Public Officials } \\
\text { - Residents } \\
\text { - } \text { Business } \\
\text { Leadership } \\
\text { - Non-Profit Groups }\end{array}$ \\
\hline
\end{tabular}




\section{Hypotheses:}

Using these elements from the literature, we can see three areas forming to create a successful downtown; Cooperation among stakeholders, public policy and programs, and quality of life variables. They can be simplified and illustrated by the following graphic: 
Figure 1.1: Diagram of a Successful Downtown

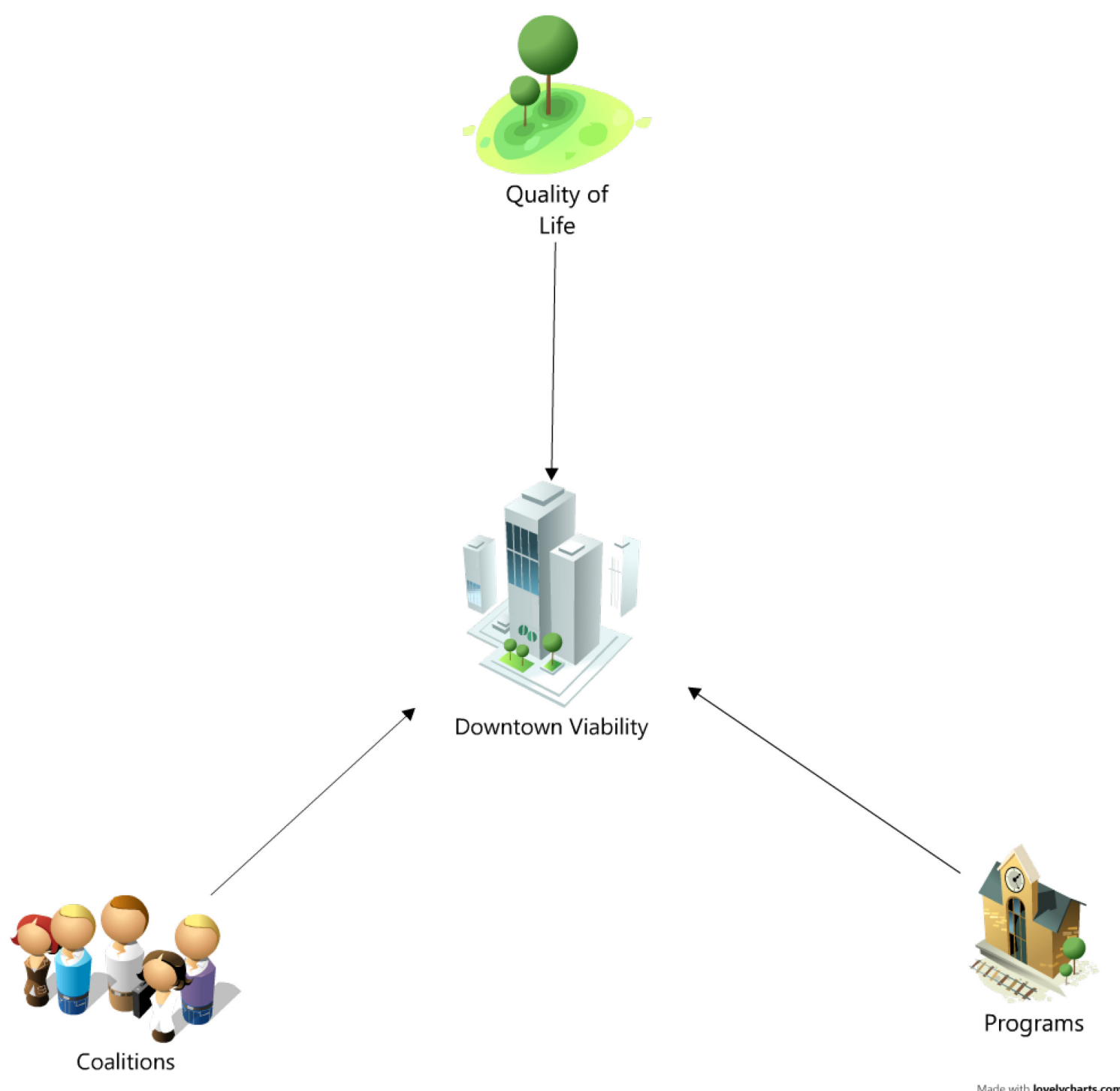


Various hypotheses can be formed around these ideas:

Hypothesis 1: Revitalization efforts that involve multiple stakeholders (business, private citizens, non-profit groups, local, state, and federal policymakers, etc.) will have a positive impact on downtowns.

Hypothesis 2: Local policymakers' public policy decisions, including zoning, subsidization, and tax policy have an impact on the shape and success of downtowns.

Hypothesis 3: Cities that have embraced and worked with federal and nonprofit groups and programs will see a noticeable impact on their downtown environments.

Hypothesis 4: Cities that have higher quality of life variables will have more successful downtowns.

Each of these can be discussed in greater detail:

Hypothesis 1: Revitalization efforts that involve multiple stakeholders (business, private citizens, local, state, and federal policymakers) will have a positive impact on downtowns.

Time and again, research has pointed out the importance of cooperation 
and discussion among all those who have a stake in downtown development. This includes city officials such as mayors, city councilpersons, city managers, and planners. The general public also has a lot at stake in downtown development, as downtowns have traditionally been centers of business, government, and culture. Obviously private business owners and developers will also have an interest in the success or failure of a central business district. Non-profit groups and other interested parties sometimes are actually formed and in existence in order to improve and maintain downtowns. Not only should these groups be speaking with one another to solve downtown problems and maintain successes, but there should actually be some level of quality cooperation among them. When all these individuals are working well together, it should result in a "better" downtown.

Hypothesis 2: Local policymakers' public policy decisions, including zoning, subsidization, and tax policy have an impact on the shape and success of downtowns.

As evident from the literature, local government officials have a wide variety of options at their fingertips for shaping city centers. Some of these include working to designate areas as Tax Increment Finance Districts (TIFs), Business Improvement Districts (BIDs), or proposing a moratorium on development in order to protect certain areas' historical value. They can charge fees to developers, user fees to individuals for using public services or working in 
a downtown area (money that can be used to reinvest in central business districts), or raise taxes. They can directly or indirectly subsidize businesses in downtown (which should have a positive impact) or businesses outside downtown (which should have a negative impact). These indirect subsidies can even include paving roads, building sidewalks, and providing police monitoring of businesses during after-hours. Even hosting parades or special events (Arts Walks, Heritage festivals, etc.) can have an impact on satisfaction with cities. Finally, as suggested above, research shows that mixed-use zoning can be a booster for city success. It could be expected that the more mixed-use the central business district is in a town or small city, the more successful it might be.

Hypothesis 3: Cities that have embraced and worked with federal and non-profit groups and programs will see a noticeable impact on their downtown environments.

Programs such as Main Street USA (a non-profit group which is part of the National Historic Trust Foundation) certainly have enough support among local policymakers to generate an interest in whether or not they successfully contribute to a "better" downtown. Indeed, almost every state in the United States has several Main Street programs operating in their cities, sometimes multiple programs within a city (Charleston, WV, for instance, has two main street programs, one for the East Side and one for the West Side.) Community Development Corporations, Historic Societies, and other non-profit groups may 
also contribute to downtown revitalization and protection. Cities may also receive support and funding from a wide variety of state, local, and federal initiatives including grant moneys. All of these programs can be expected to make a positive contribution to the overall health of downtowns.

Hypothesis 4: Cities that have higher quality of life variables will have more successful downtowns.

Although there may be some overlap between quality of life variables and the dependent variable - overall downtown quality - there is no doubt that a better quality of life helps to build a stronger city center as well. If people have good housing, access to groceries, clothing, and medical care, have adequate transportation either motorized or through walkable neighborhoods, and are safe from crime and other hazards, they will be more likely to live, work, shop, and play in downtown areas. Quality of life must be an important factor in the overall rating of a downtown's success.

These hypotheses can be tested in a way that fills major gaps in the literature and introduces a substantial methodological framework to help understand what helps create viable and successful downtowns. First, by focusing on small cities and second by doing a methodological study. Because most of the literature on downtown development comes from a qualitative perspective (even many surveys are qualitative in nature), a quantitative look could be very revealing and with a good sample perhaps more generalizable. 
Also, there is no overarching research that tries to tie perceptions of downtown quality with a broad discussion of what programs and policies might have actually worked. Instead of focusing on a single issue or problem in communities, a survey approach will allow a more inclusive view of the downtown issue. A discussion of how to test these hypotheses using surveys is the focus of the beginning of the next chapter. The methodology will be discussed in detail. 


\section{Chapter 2: The Survey Instrument}

In order to test the hypotheses from Chapter 1, an eight question survey instrument was developed (many of these questions had several sub-items to be ranked or rated by the respondents). The complete survey is presented in its original form along with a cover letter in Appendix I. This instrument had three main areas to probe in relation to the overall quality of downtowns in small cities:

1) Programs and policies implemented in a community

2) The level of cooperation between key groups within a community

3) Quality of life within a community

Below is an introduction to the survey instrument, a presentation of the survey design process, and examples of the logic behind questions and specific question wording. Following this discussion is the survey sampling process and other sampling issues including response rate. Finally summary statistics from each question are reported. In the next chapter, more advanced statistical models will be used to test hypotheses.

\section{Survey Instrument Design}

Question 1 was designed to make sure that a respondent fit within the sample targeted by the research design. It asked "Does your city have an officially defined downtown or central business district?" and respondents could answer a simple yes or no. This question was important in the design because, as the literature presented in Chapter 1 shows, downtown boundaries are sometimes vaguely defined or even a controversial topic. So, question 1 not only 
makes sure that the respondent actually fits within the sampling frame, but also tests to see just how often small cities might not have an officially defined downtown. If the respondent answers 'no' to this preliminary question, they are asked "is there a general area considered as downtown or the central business district by yourself or your community?". Respondents are considered outside the sampling frame if they answer no to both of these questions (although as shown below in the sampling process, great care was taken to exclude communities who have no downtown from the survey process). Question 1 is a final safeguard to make sure all respondents can reasonably answer the following questions in the survey. "Yes responses were coded 1 and No responses 0 . No response/Did not answer on this question and all subsequent questions was coded as 999.

Question 2 aims to target quality of life and programs and policy issues within the frame of mixed use zoning laws (See hypothesis 2). It asks "How much of your downtown is zoned for mixed uses (some combination of residential, commercial, office, industrial, or other land uses)?" and allows the respondent to answer on a four point scale - none (coded 1), a little (2), a lot (3), and all (4). Since mixed use zoning is generally a policy decision by local government officials and helps to describe what types of activities take place in downtown (can people live, work, shop, eat, etc. in the same space?), it bridges policy issues and quality of life. The question was careful to give examples of 
things that could be considered "mixed-use" in case there was any confusion or lack of clarity among respondents.

Question 3 helps establish a measurable dependent variable in the model. By asking "Overall, how would you rate your downtown?", we get a quick measure of viability that can be used in regression models. This item could potentially be biased, as one could argue that individuals might rate their city higher than it would be in a more objective examination. There are three important considerations to think of regarding this potential bias. First, all surveys suffer from the same potential for bias when they ask respondents to make normative judgments. Secondly, when the summary results of this question are discussed, they will incorporate an analysis of the responses to see whether or not they were highly biased. Finally, this question can be used alongside a different model of overall downtown health in order to determine potential bias. The respondents could choose from a 5 point rating scale from poor to excellent when answering. Responses were coded 1 (Poor), 2 (Below Average), 3 (Average), 4 (Good), 5 (Excellent).

Question 4 asks "How well would you say the general public, business owners, non-profit groups, and elected officials work together to maintain or improve your community?" This question specifically targets the hypotheses and literature about cooperation among key stakeholders. It is a general overarching question that attempts to get a measure of overall cooperation among everyone in a community rather than a series of questions about each relationship. After 
all one or two strongly supporting or opposing forces from any of these groups can make a large impact on the success or failure of downtown revitalization and development efforts (Flora 2003). Again the five point rating scale from poor to excellent is used. Responses were coded 1 (Poor), 2 (Below Average), 3 (Average), 4 (Good), 5 (Excellent).

Survey question 5 asks the respondent about a series of programs and policies which are or have been active in downtown, which targets hypotheses about their important role in the development and maintenance of city centers. Specifically, the question is worded as "Which of the following programs/policies are or have been active in the last ten years in your downtown or central business district? Please select all that apply". It was important to capture not only ongoing policies and programs but also things that had happened in the recent past. Discussions with other experts on local policy suggested that ten years might be a fair amount of time to capture most variables that have an impact on the current state of a downtown or central business district. It is possible that some events might have had an impact much further back than this, but as time goes on it becomes almost impossible to determine how many programs and policies over the course of a city's history could have a potential impact, so ten years was seen as a good cut-off point.

The list of policies and programs came from three sources. First, they were taken from the literature that was presented in Chapter 1 (See especially Bengsten, et. al 2004 and Farst 2003). Policies and programs that were 
discussed or hypothesized to be important to city vitality were included in the list. Secondly, surveys that had been published or discussed in publications about city development that included lists of policies and programs offered up several more items to be included (Farst 2004, Sakamoto 1995, Mitchell 2001, Walzer and Kline 2001). Finally, during pre-screening of the survey by colleagues and other experts some more items were included in question 5 . These sources led to a fairly exhaustive list that allowed respondents to quickly indicate what programs and policies might have affected their current downtown status. A check mark indicating the program is or was active was coded 1 and if it was not checked was coded 0 . Other responses were directly recorded. The final list included the following sub-items. Included here is a short explanation of each:

- Tax Increment Financing (TIFs): Commonly referred to as "TIFs", Tax Increment Financing is a method used since the 1950 s for state and local government to fund projects that are believed to have a high payoff in increased tax revenues over the coming years. An initial debt is incurred in order to spur building or other redevelopment projects with the assumption that tax revenues will increase as a result of the project. The increase (or increment) of these taxes is used to pay off the debt that was initially incurred. TIFs are becoming increasingly more common in the United States, as discussed in Chapter 1. 
- Real Estate Tax Abatements: With this policy, cities can allow businesses to build improvements to property and agree to tax them at preimprovement rates for a given period of time (such as 10 years). The hope here is that it will encourage the construction or improvement of certain districts by giving developers an extra incentive to fix up properties without the fear of immediate tax increases.

- User Fees: The classic example of a government user fee is a toll road where drivers pay a fee to use the roadway. More recently, some cities have begun charging a "user fee" to those who work within a city. These fees can be used to make various improvements downtown.

- Developer Fees: Fees that are charged to developers for new development that takes place within the city, sometimes argued to offset the public cost of new development (such as running waterlines or public roads to a new housing development).

- Tax Credits: Allows the developer of new construction or remodeling to use a percentage of the costs of development as a tax credit.

- Debt Financing: Cities will sometimes borrow money and use the debt to finance revitalization or development with the hopes that it can be paid back with the increased income from the project. 
- Main Street Program: A national program that sets up offices in chosen downtowns across the United States and attempts to attract business, cooperation, and events to downtown areas in order to make them more attractive to visitors and residents. They are a division of the National Trust for Historic Preservation.

- Formal Policy Encouraging Private Development: Covers any sort of policy that might encourage private development in downtown but not be covered by the other categories presented here. It was important to include because of the diverse types of local governments and ideas they might have implemented in order to strengthen their downtown districts.

- Federal Grants to fund downtown development: Federal funding that went towards the downtown area.

- State/Local Grants to fund downtown development: State or local funding that went to the downtown area.

- City sponsored festivals/activities/events: Events such as "Chocolate Lover's Day" and "Arts Walks" that seem to be becoming more common in downtown areas over recent years. These are meant to draw in visitors from outside areas and introduce them to businesses and opportunities that are available in a local central business district.

- Use of eminent domain/public acquisition: Local, state, or federal government will sometimes use different means to acquire privately owned property and use it for the general good of the population. 
- Development moratoria: This policy prevents development in certain areas or of certain types of businesses (for instance to protect the integrity of a historical district within a city or to prevent a "big-box retailer" from being constructed near smaller locally owned businesses.)

- Community Development Corporations: Commonly referred to as CDCs, these are non-profit organizations that are formed to provide some services to a neighborhood or district of a city.

- Non-Profit Grants to fund downtown development: Funding from a nonprofit source used to improve the downtown area.

- Historic Society/Trust Program: A program, group, or committee that serves to monitor and protect the historic neighborhoods, buildings, and other property that exists in a city.

- Direct Subsidies for businesses located downtown: Directly giving funding to a business downtown.

- Indirect Subsidies (roads, sewage, water, etc.) for Businesses located downtown: Providing roads, utilities, or other valuable services to businesses that are located downtown free of charge or at a discounted rate.

- Direct Subsidies for businesses located outside downtown: Directly giving funding to a business located outside downtown. 
- Indirect subsidies (sewage, water, etc.) for businesses located outside downtown: Providing roads, utilities, or other valuable services to businesses that are located outside downtown free of charge or at a discounted rate.

- Public policies for managing urban growth: Any policy that would help contain growth within a downtown district or refrain from development "sprawl".

- Urban Growth Boundaries: These are defined geographic areas that mark the only places where high density development is allowed.

- Urban Service Boundaries: Sometimes used as another name for Urban Growth Boundaries (which can sometimes function as practically the same, but both need to be included for local usage), these geographic areas specifically limit where public services can be provided to development, with the hopes of containing high density development within a certain region and prevent sprawl.

- Business Improvement Districts: These are agreements between cities and businesses in an area that the business will pay an additional fee or tax in order that the city can improve other elements of the district around the business (with the hope that it will garner them greater profits or make their business more valuable). 
- Other: 4 blanks were left for respondents to include any other policies or programs active in their communities. These will be discussed in the summary results of each question later.

Question 6 generally targets quality of life variables, although a few of the sub-items also indicate programs and policies (such as support from state and local government). Not only can these be used to make up a proxy measure of quality of life, they can arguably also be made to create a different measure of the overall health of downtown and used as a comparison with question 3. At the very least, they provide a more detailed look at how respondents view their downtowns and get them to think in different terms from just the overall picture. It asks "How would you rate the following in your downtown/central business district? Please select the appropriate box to rate each of the issues below." Respondents are then given a list of 22 items and asked how they rate from "poor" to "excellent" in their downtowns. Again, these are coded from 1 (poor) to 5 (excellent). The items are as follows:

- Quality/Availability of Groceries

- Quality/Availability of Restaurants

- Quality/Availability of Shopping

- Quality/Availability of Downtown Housing

- Quality/Availability of Public Transportation

- Quality/Availability of Schools

- Quality/Availability of Colleges and Universities 
- Quality/Availability of Health Care

- Arts and Cultural Opportunities

- Pedestrian Safety

- Safety from Crime

- Employment Opportunities

- Tolerance of Diversity

- Attractiveness of Downtown

- Parking

- Quality/Availability of Parks and Greenspace

- Quality/Availability of Hotels

- Availability of Government Services

- Usage of Downtown During Non-Standard Business Hours (Note: In order to capture a picture of nightlife, bars, late night eating and other entertainment, a well thought out question wording was needed. If, for instance, the question was "Nightlife", someone might rank it as "poor" even if nightlife was booming because they disagreed with the type of nightlife that was going on (such as a college town where students heavily frequent bars but might not be seen as positive to locals). This question allows us to see how the downtown might be utilized without getting a moral or normative reaction to the usage.

- Ability to compete with shopping outside downtown

- Support for downtown from your state government 
- Support for your downtown from the federal government In order to gauge where the downtown is headed (and partially to gauge how successful the efforts have been - after all, if a really good downtown with many programs and policies in place, but it is headed in a negative direction, then programs and policies might be hindering rather than helping the development process, question 7 was developed: "Assuming thing stay on the same course, what direction do you think your downtown is headed in over the next 10 years?" Respondents could choose from "a positive direction" (coded 3), "it will stay about the same" (coded 2), and "a negative direction" (coded 1). Ten years was selected as an important time frame since it forces the respondent to think over the longer term rather than just short term gains, and perhaps longer than their individual public service might take place.

Question 8 was "What is the biggest challenge facing your downtown's development?". Respondents could choose from:

- Quality of Life Issues (1 - coded to include housing issues and most of the issues that were mentioned in question 6.)

- Lack of cooperation between public, private, and non-profit groups (2)

- Lack of adequate public policy/programs (3)

- Lack of finances for development (4)

- Failure of downtown to compete in the marketplace (5)

- Other (Could list anything).

Coding question 8 became increasingly hard as policymakers began 
choosing to respond with several problems instead of choosing a single one.

The breakdown of coding is as follows:

\begin{tabular}{|l|l|}
\hline Responses to Question 8 & Coding \\
\hline Quality of Life Issues & 1 \\
\hline $\begin{array}{l}\text { Lack of Cooperation between public, private, and non-profit } \\
\text { groups }\end{array}$ & 2 \\
\hline Lack of adequate public policy/programs & 3 \\
\hline Lack of finances for development & 4 \\
\hline Failure of downtown business to compete in the marketplace & 5 \\
\hline Lack of finances and failure to compete & 6 \\
\hline Lack of cooperation and lack of finances & 7 \\
\hline Lack of cooperation, lack of finances, and failure to compete & 8 \\
\hline Quality of Life Issues and Lack of Finances & 9 \\
\hline Lack of adequate public policy/programs and lack of finances & 10 \\
\hline Quality of Life Issues and failure to compete & 11 \\
\hline $\begin{array}{l}\text { Lack of cooperation, lack of public policy/programs, lack of } \\
\text { finances, and failure of downtown to compete }\end{array}$ & 12 \\
\hline Lack of public policy/programs and failure to compete & 13 \\
\hline $\begin{array}{l}\text { Quality of life issues, lack of cooperation, lack of finances, and } \\
\text { failure to compete }\end{array}$ & 14 \\
\hline Lack of cooperation and failure to compete & 15 \\
\hline Lack of cooperation and lack of policies/programs & 16 \\
\hline $\begin{array}{l}\text { Lack of cooperation, lack of policies/programs, and failure to } \\
\text { compete }\end{array}$ & 17 \\
\hline $\begin{array}{l}\text { Quality of life issues, lack of cooperation, lack of } \\
\text { programs/policies, lack of finances, and failure to compete }\end{array}$ & 18 \\
\hline Quality of life issues, lack of cooperation, and failure to compete & 19 \\
\hline Quality of life issues, lack of finances, and failure to compete & 20 \\
\hline $\begin{array}{l}\text { Lack of cooperation, lack of public policy/programs, and lack of } \\
\text { finances }\end{array}$ & 21 \\
\hline Quality of life issues and lack of cooperation & 22 \\
\hline
\end{tabular}


This question allows us to compare perceptions of challenges with our model that tests what seems to impact the overall health of downtowns. In other words, do respondents have a valid understanding of what problems are hindering their downtowns and an idea of what they could do to help improve the city?

Question 9, "Would you say your downtown is a good place to raise a family?" serves as another proxy of quality of life issues. Taken as a whole, this question could indicate how the overall quality of life in a downtown is. It can be compared to the overall assessment of downtown and used in models as a quality of life predictor of downtown condition.

\section{Sampling and Survey Procedures}

Because of the technical nature of some of these questions, the general population including residents was not seen as a valid sample for the survey design. While they could render judgments on the overall quality of city centers and the quality of life within them, it could be assumed they would not know all the policies and programs that were active in a downtown, the amount of mixeduse zoning present in a community, challenges faced by communities, nor the level of support from non-profit and other levels of government. In fact, depending on how long they were residents, they also may not be able to make valid assessments of the quality of a city. It could be noted here that an interesting future supplement to this study would be to survey residents and compare their assessments of downtown to the programs and policies that were 
suggested as in use by respondents. Instead, it seemed feasible and useful to limit the target population to policymakers within local government. Individuals such as mayors, councilpersons, city managers, and planners would be in a position to know the details of programs and policies and should be able to give an informed view of the overall quality of life in a downtown. These individuals also know the level and quality of cooperation with other stakeholders in the community, as they deal with them on a day to day basis. Three local officials who were not included in the final survey population were asked to review the survey instrument before its implementation and give feedback, which provided the final tweaks and a small "pre-test" to the questionnaire.

Obviously, resources limit the sheer number of policymakers who can be surveyed by the instrument. Because a national survey would present results that could best be generalized to small cities as a whole, there needed to be a way to limit the number of surveys to a manageable amount while still getting a representative sample of the country as a whole. Each state has a number of U.S. Congress House of Representatives members based on its population, which seemed a good starting point to get a representative number of cities within each state. West Virginia, for instance, has three representatives, so three cities were selected from the state. This comes to a grand total of 435 cities (one for each house member in each state). To get a good number of responses, two local government officials (the mayor and the city manager or planner if possible) 
from each city were selected to receive surveys, making a total of 870 surveys to be mailed.

Next, it was necessary to select a random sample of cities to measure. The U.S. Census Bureau keeps "Quickfacts" on cities with a population above 25,000 . Since a population between 25,000 and 100,000 seems to be a fair estimate of what makes a "small city", this list was convenient to use in the creation of a list of cities. Each state has cities listed in alphabetical order. Within that list, only those cities with a legitimate downtown area were considered for the survey because the instrument exclusively asks questions that are targeted at places who actually have a city center, downtown, or central business district. Suburban cities that have no core are irrelevant to this study, as the purpose is to know what affects the health of downtowns. Each city had to be individually examined to see if it fit the eligible criteria of having a downtown. This was done in a multi-step process, which taken as a whole gave a good idea of whether a city had a downtown or not:

- City websites: Almost every city within the population range had an officially designed website with information about the city. This website was extensively examined to see if there was mention of a downtown with regard to planning, zoning, or a downtown business district or association.

- Main Street/Downtown Association Websites: Many cities had websites specifically dedicated to their downtown or to an association meant to strengthen downtown. 
- GIS analysis: If a downtown had not yet been confirmed, using Google Maps software (including Google Street View, which gives a first person perspective of downtowns), the streets of each town were examined to see if a business district existed downtown. The layout of the town as well as street view indicated in many cases if a town was a suburban municipality that had grown above 25,000 .

- General internet search for downtown: Finally, a general internet search provided in many cases a view of whether or not a city had a downtown. Taken as a whole, it seems that this method was able to accurately find out if city did or did not have a downtown or central business district. Even nonofficially defined downtowns were found via Google Street View and official websites of the cities. The error was generally perceived to be very low (and will be discussed more in the results section).

Cities were chosen at random from the possible selections. West Virginia, for instance, has five "small cities" with populations between 25,000 and 100,000 with a downtown area. Because they only have three representatives in the U.S. House, a random three numbers were selected from the possible five, and those cities were selected from the list (Charleston, Huntington, and Parkersburg were chosen). Each of these cities received two surveys addressed to different public officials. Because one state, Hawaii, had too few cities to chose from (only one city was eligible and two United States House of Representatives members), that 
brought the total number of cities to 434 and the total number of surveys mailed sent out to 868 .

In satisfaction with West Virginia University's Institutional Review Board requirements, the surveys were sent with a cover letter (Appendix I) explaining the nature and purpose of the survey and an anonymous, postage pre-paid business reply envelope for their responses to be sent back to the Institute for Public Affairs. Addresses were chosen from publicly available sources, mainly official city websites. 17 of the surveys were returned as undeliverable for a final surveyed population of 851 local government officials. 263 completed surveys were returned for a final response rate of $30.9 \%$. Margin of error was not calculated because it is impossible to know for sure the total population of small cities and possible respondents in the entire United States. A guess at the margin of error would thus be somewhat arbitrary.

Using a color-coding scheme differentiating between mayors and city planners/managers, it was possible to see which of the two groups responded. 163 of the surveys came from city managers/planners $(62.0 \%)$ and 100 from mayors (or in a few rare cases when a mayor was not available, another city council member). Ethics concerns would not allow each address of the respondents to be directly tracked. The small number of cities in some states (2 or 3 in some cases) could create potential anonymity concerns. Surveys were mailed back from at least 30 different U.S. states, however, as per the postmark 
on the returned responses which were counted and analyzed separately from the surveys. Of course, all surveys did not include a legible postmark.

\section{Summary Results}

The following are the summary results and statistics on each question along with a discussion, where appropriate, of what some of the findings may mean for the study of downtown development.

Table 2.1

Question 1: “Does your city have an officially defined downtown or central business district?"

\begin{tabular}{|c|c|}
\hline Yes (1) & $89.31 \%$ \\
\hline No (0) & $10.69 \%$ \\
\hline
\end{tabular}

Table 2.2

Question 1b: "If no, is there a general area considered the downtown (or central business district) by yourself or your community?"

\begin{tabular}{|c|c|}
\hline Yes (1) & $89.30 \%$ \\
\hline No $(0)$ & $17.86 \%$ \\
\hline
\end{tabular}


The results here show that the efforts to find eligible communities that actually had downtowns were very successful. In fact, a total of only three responses said they had no officially or unofficially defined downtown (less than $1 \%$ of the total responses) and $99 \%$ answered in the affirmative. This gives some validity to the process used to select cities that had downtowns. The three cities who did not have a downtown were unable to answer the remainder of the survey and thus excluded from the remainder of the discussion here..

Table 2.3

Question 2: "How much of your downtown is zoned for mixed uses (some combination of residential, commercial, office, industrial, or other land uses)?"

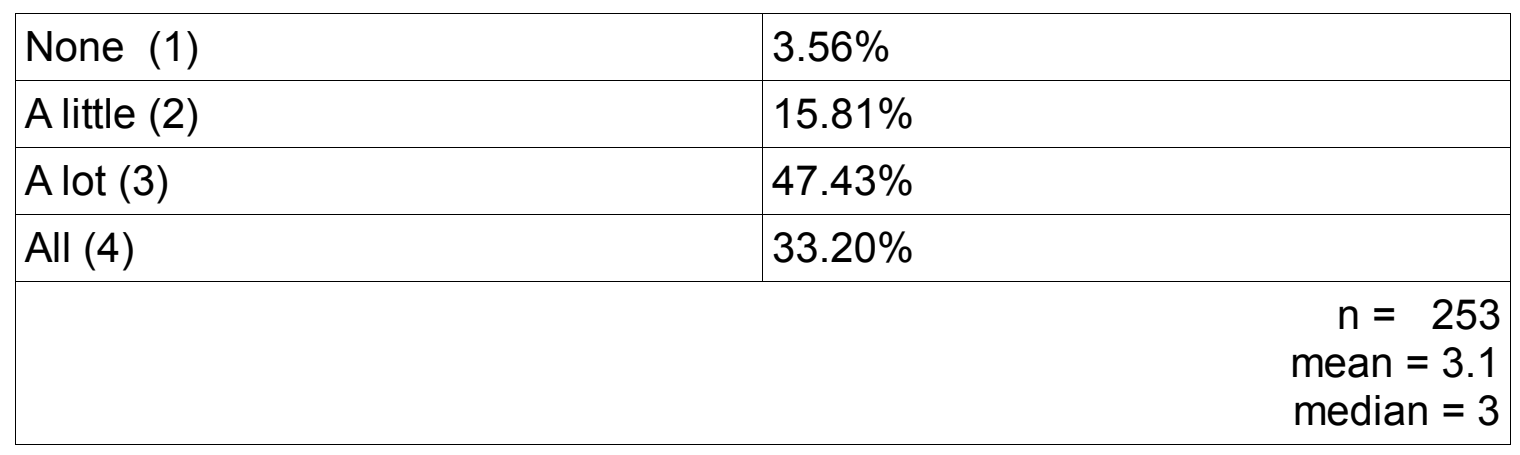

As might be expected, the majority of downtowns have a lot or all of their space zoned as mixed-use. There is quite a bit of variation, however, from city to city on just how much of the downtown is mixed-use. This can be important when comparing to the literature about zoning and the importance mixed-use zoning has to successful downtowns (Levine 2005). 
Table 2.4

Question 3: "Overall, how would you rate your downtown?"

\begin{tabular}{|c|c|c|}
\hline Poor (1) & $4.28 \%$ & \\
\hline Below Average (2) & $19.84 \%$ & \\
\hline Average (3) & $23.35 \%$ & \\
\hline Good (4) & $35.80 \%$ & \\
\hline Excellent (5) & $16.73 \%$ & \\
\hline
\end{tabular}

As previously stated, this question introduces the question of bias among respondents to rate their cities higher than they might actually be. $47.5 \%$ of respondents ranked their city "average" or lower. That indicates that there may be a slight bias towards a higher rating, but not one that is extensively large. It seems that many people were at least willing to assess their city as average and below average. Indeed, only $16.7 \%$ of respondents claimed their city to be "excellent". Part of the bias could also be because respondents may have been more likely to be involved in community development and revitalization efforts (they would be more interested in the issue, and perhaps slightly more interested in filling out the survey and returning it). It is important, however, to note that this potential for a small amount of bias is reason enough to check this measure against other measures of the overall health of downtown communities. 
Table 2.5

Question 4: "How well would you say that the general public, business owners, non-profit groups, and policymakers work together to improve or maintain your downtown?"

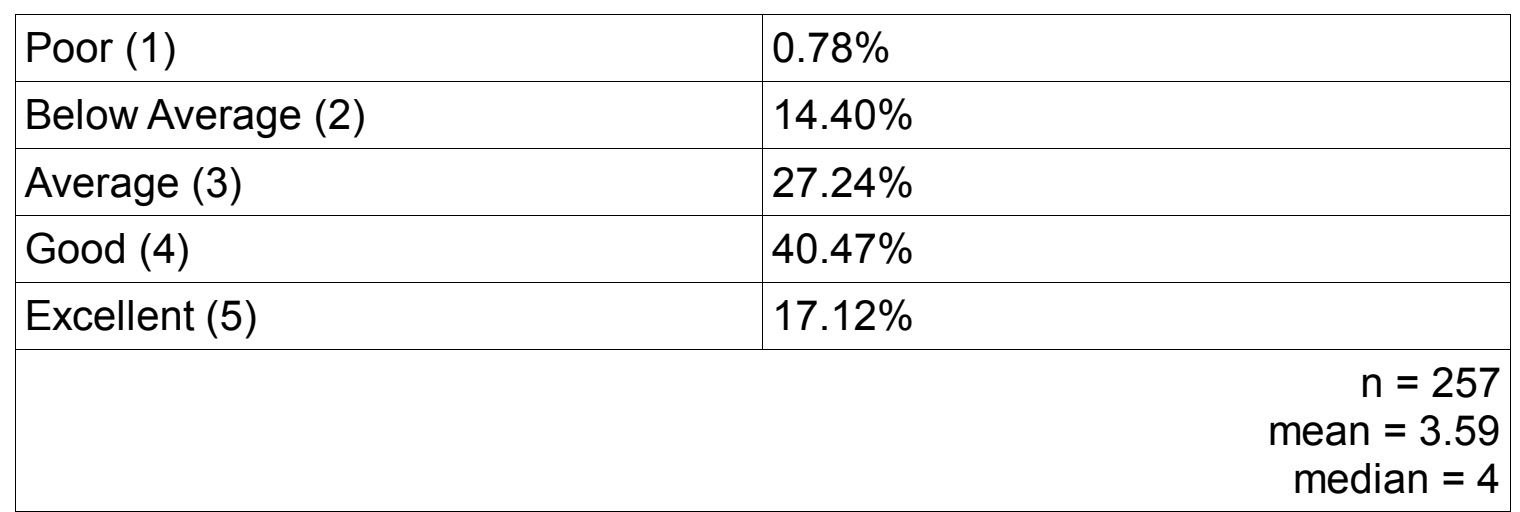

The results here came as slightly surprising, as local officials seemed to have a highly positive view of their working relationship with other groups in the community. Of course, this might be a function of the high self-assessments of downtown (earlier it was hypothesized that quality cooperation between stakeholders would lead to better downtowns). That relationship will be examined in the next chapter in greater detail. 
Table 2.6

Question 5: "Which of the following programs/policies are, or have been active in the last ten years in your downtown (or central business district)? Please select all that apply.

Tax Increment Financing (TIFs)

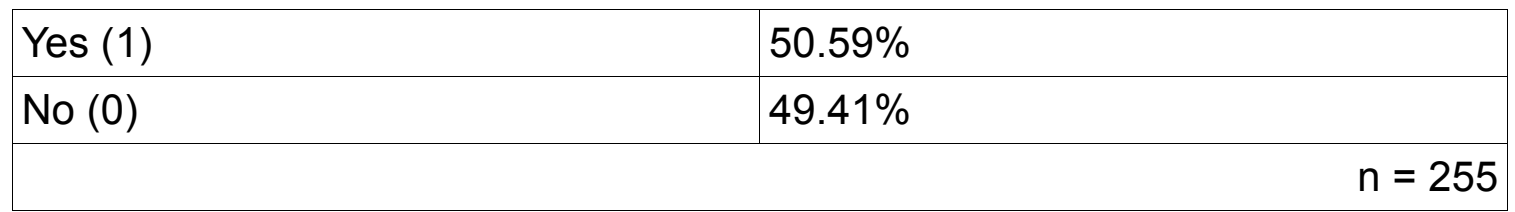

While over half of the population may seem high, TIFs are quickly becoming one of the most used tools in downtown development in use in the United States. It would be expected that half of the communities surveyed would be using TIFs for one purpose or another especially considering 49 states and the District of Columbia have authorized their use (Burayidi 2010).

Table 2.7

Real Estate Tax Abatements:

\begin{tabular}{|c|c|}
\hline Yes (1) & $17.65 \%$ \\
\hline No (0) & $82.35 \%$ \\
\hline
\end{tabular}


Table 2.8

User Fees

\begin{tabular}{|c|c|}
\hline Yes (1) & $16.08 \%$ \\
\hline No (0) & $83.92 \%$ \\
\hline
\end{tabular}

Table 2.9

Developer Fees

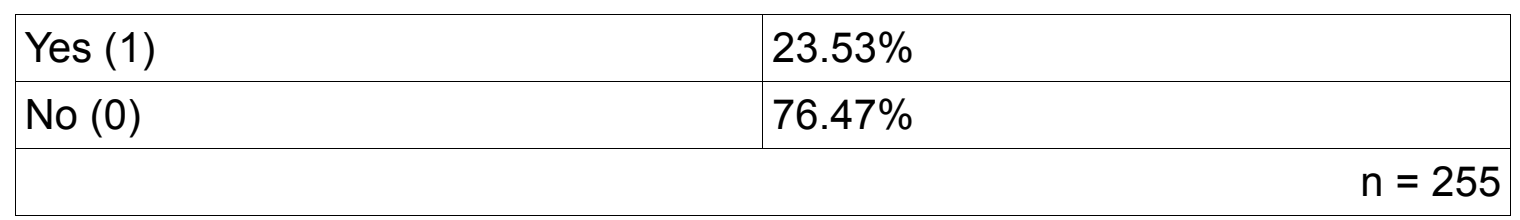

Table 2.10

Tax Credits

\begin{tabular}{|c|c|c|}
\hline Yes (1) & $25.88 \%$ & \\
\hline No $(0)$ & $74.12 \%$ & \\
\hline \multicolumn{3}{|c|}{$\mathrm{n}=255$} \\
\hline
\end{tabular}


Table 2.14

Federal Grants to fund downtown development

\begin{tabular}{|l|l|}
\hline Yes (1) & $36.86 \%$ \\
\hline No $(0)$ & $63.14 \%$ \\
\hline & \\
\hline
\end{tabular}

Table 2.15

State/Local Grants to fund downtown development

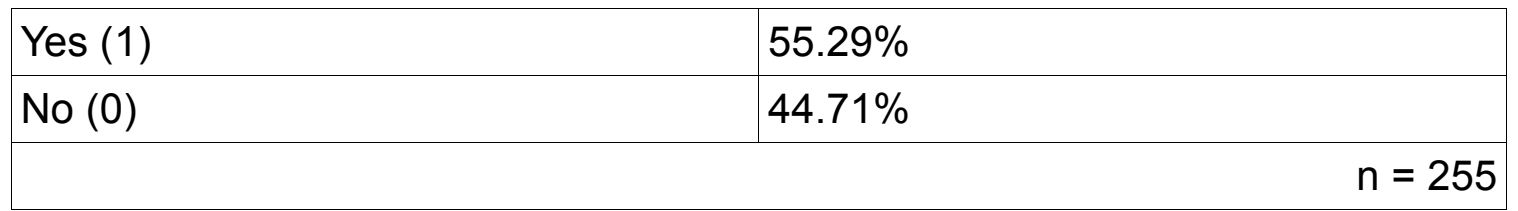

It was interesting to compare the last two sub-items to find that downtown development seems to rely more heavily on state and local grants and support than on the federal government. This could have implications for states to consider that they must bear the most substantial economic burden when it comes to revitalizing downtown. The importance of the local, regional, and statewide role has been emphasized in the literature as well (Fox and Treuhaft 2005). 
Table 2.16

City sponsored festivals/activities/events

\begin{tabular}{|c|c|}
\hline Yes (1) & $88.63 \%$ \\
\hline No (0) & $11.37 \%$ \\
\hline
\end{tabular}

The high percentage of respondents indicating their city had a festival or other activity is important because it illustrates the growing importance that many are placing on these types of event. This has been a major focus of the Main Street USA program for quite some time (Smith 1996) and is considered to be one of the most important ways for cities to advertise and draw others into downtown (Burayidi 2000 and Hechesky 2005). Perhaps the reported high success rate of these events has spread their use across the majority of small cities in the United States (Hechesky 2005).

Table 2.17

Use of eminent domain/public acquisition

\begin{tabular}{|c|c|}
\hline Yes (1) & $24.31 \%$ \\
\hline No $(0)$ & $75.69 \%$ \\
\hline
\end{tabular}


Table 2.18

Development moratoria

\begin{tabular}{|c|c|}
\hline Yes (1) & $6.27 \%$ \\
\hline No $(0)$ & $93.73 \%$ \\
\hline
\end{tabular}

This could indicate that the majority of local governments do not see development moratoria as a valid or useful community development tool. This may be because they tend to believe any development is good development and serves as a flag to examine further how policymakers might understand smart development and growth. As mentioned in Chapter 1, moratoria are rarely mentioned in the literature, and the small utilization of this tool by small cities may be one reason why this could be the case.

Table 2.19

Community Development Corporations

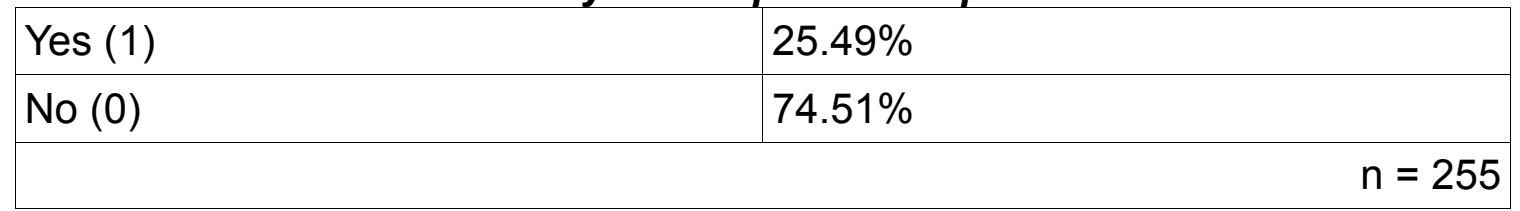


Table 2.20

Non-Profit Grants to fund downtown development

\begin{tabular}{|l|l|}
\hline Yes (1) & $50.59 \%$ \\
\hline No $(0)$ & $49.41 \%$ \\
\hline & \\
\hline
\end{tabular}

Here, it should be briefly noted that we see a very high involvement of the non-profit sector in downtown revitalization and development, almost as high as state and local government. This could be expected given the involvement of many non-profits, especially Main Street USA in revitalization efforts across the country (Smith 1996).

Table 2.21

Historic Society/Trust Program

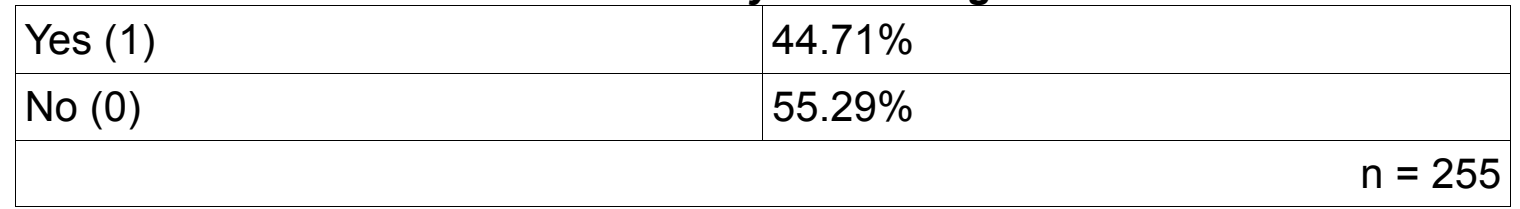


Table 2.25

Indirect Subsidies (roads, sewage, water, etc.) for businesses located outside downtown

\begin{tabular}{|l|l|}
\hline Yes $(1)$ & $16.47 \%$ \\
\hline No $(0)$ & $83.53 \%$ \\
\hline & \\
\hline
\end{tabular}

It is interesting to note that local officials claim to support downtown businesses to a much greater extent than those outside downtown in both direct and indirect subsidies. The results of the survey questions on indirect subsidies, however, raise a curious eye. The way the question was defined (with roads) would indicate an almost $100 \%$ subsidization rate (unless there was a rare case where the city believed businesses, even outside the city center, paid the full price for the roads and sidewalks the city built and maintained or a case where the state may be responsible for all roads and thus the city does not see it as a subsidy coming from itself).

Nevertheless, it seems odd that only $16.47 \%$ of respondents felt they were in any way indirectly subsidizing businesses outside the downtown core. There are several possibilities here. One is that the various definitions of indirect subsidies that do not match the spirit of the question wording. Another possibility is that officials do not perceive how their public works projects can be indirect subsidies to business both inside and outside downtown.

It is very possible that individuals do not realize all the indirect subsidies that go to business, especially since projects such as water, sewage, roads, and 
other infrastructure are so commonplace that they may not be taken into consideration when thinking about new development and competing business. Some businesses who receive benefits from the city may even lie outside its limits and be completely overlooked when subsidization is discussed. If so, educating officials on subsidization consequences of their actions could sway the balance between (unfair?) competition and success among downtowns and outside districts.

There are also commonly disputes between cities and the county or regional government around them. It is possible that cities see the suburban communities or county government as responsible for the subsidies rather than themselves. These potential reasons for the responses to this survey item are simply suggested possibilities and should be considered further in other research.

Table 2.26

Public policy for managing urban growth

\begin{tabular}{|c|c|}
\hline Yes (1) & $33.73 \%$ \\
\hline No (0) & $66.27 \%$ \\
\hline
\end{tabular}


Table 2.27

Urban Growth Boundaries

\begin{tabular}{|c|c|}
\hline Yes (1) & $15.29 \%$ \\
\hline No (0) & $84.71 \%$ \\
\hline
\end{tabular}

Table 2.28

Urban Service Boundaries

\begin{tabular}{|c|c|c|}
\hline Yes (1) & $9.84 \%$ & \\
\hline No $(0)$ & $90.16 \%$ & \\
\hline \multicolumn{3}{|c|}{$\mathrm{n}=255$} \\
\hline
\end{tabular}

Because the terms Urban Growth Boundaries and Urban Service Boundaries are sometimes used interchangeably in research and discussion of downtown development (Daniels 2001, Handy 2005, Brueckner 2000), the results here suggest that either policymakers see the small differences that may exist between the two, or that local officials should be educated more about the academic uses of the terms. To be specific, 23 respondents (just over 9\%) claimed to have urban growth boundaries and not urban service boundaries and 9 respondents (3.5\%) claimed to have USBs and not UGBs. It is impossible to say for sure which of these is true, but it does have important implications for a practical discussion between researchers and practitioners about the meaning of 
these two terms. It can also be noted that UGBs and USBs are a type of "urban growth policy" and thus also fall under that item as well.

Table 2.29

Business Improvement District

\begin{tabular}{|l|l|}
\hline Yes $(1)$ & $7.06 \%$ \\
\hline No $(0)$ & $92.94 \%$ \\
\hline & \\
\hline
\end{tabular}


Other (Please List):

The following were other responses that did not seem to fit or could not be coded into the categories listed above:

- 244 of 255 respondents listed no "other" policies and programs

- Transit Mall

- Beautification Program (3)

- Parking District

- Funding downtown manager

- incentive grants based on new property

- low interest loans for facade improvements

- park development

- parking waivers

- urban renewal

Because of the small amount of "other" programs and policies listed, and how infrequently each appeared (only beautification program showed up more than one time), it is assumed that the survey was originally designed taking into account the most prominent programs and policies in use in communities around the United States. That gives some face validity to the survey itself. 
Table 2.30

Question 6: "How would you rate the following in your downtown/central business district? Please select the appropriate box to rate each of the issues below.

\section{Quality/Availability of Groceries}

\begin{tabular}{|c|c|c|}
\hline Poor (1) & $38.28 \%$ & \\
\hline Below Average (2) & $22.66 \%$ & \\
\hline Average (3) & $15.23 \%$ & \\
\hline Good (4) & $16.02 \%$ & \\
\hline Excellent (5) & $7.81 \%$ & \\
\hline & & $\begin{array}{r}\mathrm{n}=256 \\
\text { mean }=2.32 \\
\text { median }=2\end{array}$ \\
\hline
\end{tabular}

Returning to the question of bias among respondents, it becomes evident from these results that respondents are giving sometimes brutally honest assessments of different elements of the quality of life in their downtowns. Here, for instance, $38.28 \%$ (the highest category) of respondents said the quality/availability of groceries in their downtown/central business district was "poor". From the mean and median, we also see that this is a major problem in downtowns and that over half of respondents $(60.94 \%)$ believed groceries to be "below average" or "poor". Groceries are essential to create a truly livable and walkable downtown, which in turn helps create success (Florida 2003, Levine 2005, Burayidi 2001, Daniels 1995, and Robertson 1995). Obviously individuals who have to drive to the supermarket outside the city center will drive profits 
away from downtown and continue to contribute to the growth of sprawl and suburbia.

Table 2.31

Quality/Availability of Restaurants or Cafes

\begin{tabular}{|c|c|c|}
\hline Poor (1) & $2.75 \%$ & \\
\hline Below Average (2) & $15.69 \%$ & \\
\hline Average (3) & $20.39 \%$ & \\
\hline Good (4) & $29.80 \%$ & \\
\hline Excellent (5) & $31.37 \%$ & \\
\hline & & $\begin{array}{r}\mathrm{n}=255 \\
\text { mean }=3.71 \\
\text { median }=4\end{array}$ \\
\hline
\end{tabular}

Table 2.32

Quality/Availability of Shopping

\begin{tabular}{|c|c|c|}
\hline Poor (1) & $7.60 \%$ & \\
\hline Below Average (2) & $31.20 \%$ & \\
\hline Average (3) & $32.00 \%$ & \\
\hline Good (4) & $20.40 \%$ & \\
\hline Excellent (5) & $8.80 \%$ & \\
\hline & & $\begin{array}{r}\mathrm{n}=250 \\
\text { mean }=2.92 \\
\text { median }=3\end{array}$ \\
\hline
\end{tabular}


Table 2.33

Quality/Availability of Downtown Housing

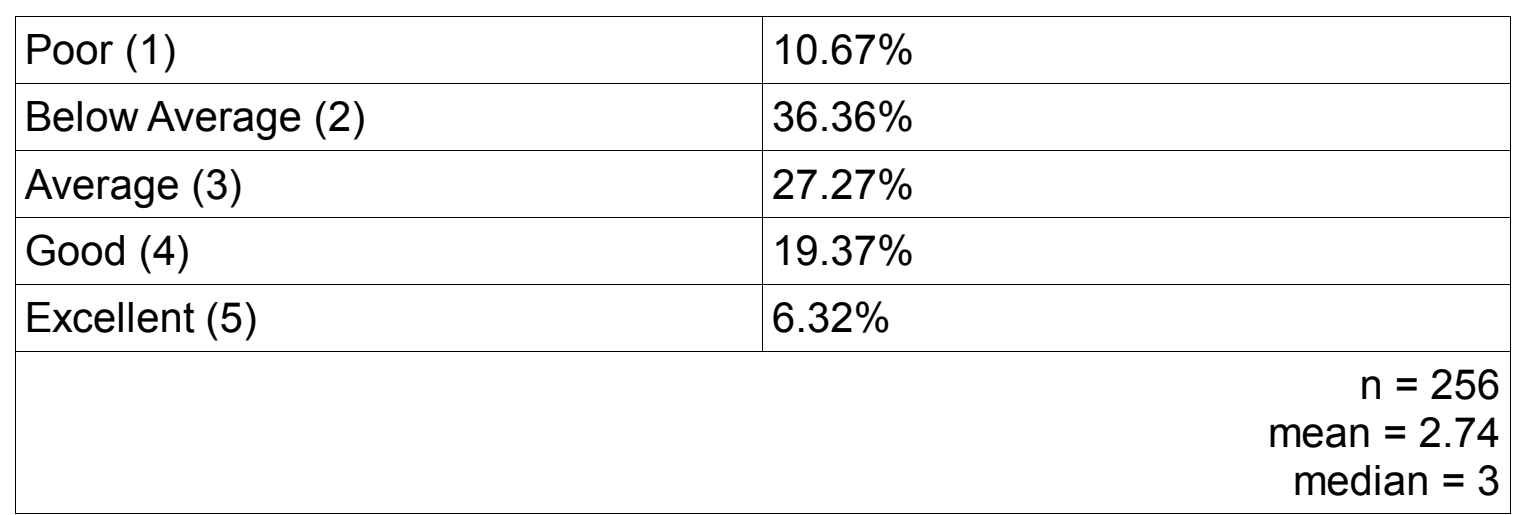

Again, the last few items including housing, restaurants, and shopping all interact with mixed-use zoning and the idea that livable communities are more successful downtowns as a whole. 
Table 2.34

Quality/Availability of Public Transportation

\begin{tabular}{|l|lr|}
\hline Poor (1) & $11.02 \%$ & \\
\hline Below Average (2) & $11.42 \%$ & \\
\hline Average (3) & $26.77 \%$ & \\
\hline Good (4) & $30.71 \%$ & $\mathrm{n}=254$ \\
\hline Excellent (5) & $20.08 \%$ & mean $=3.37$ \\
& & median $=4$ \\
\hline
\end{tabular}

Table 2.35

Quality/Availability of Schools

\begin{tabular}{|c|c|c|}
\hline Poor (1) & $7.94 \%$ & \\
\hline Below Average (2) & $15.87 \%$ & \\
\hline Average (3) & $28.97 \%$ & \\
\hline Good (4) & $26.98 \%$ & \\
\hline Excellent (5) & $20.24 \%$ & \\
\hline & & $\begin{array}{r}\mathrm{n}=252 \\
\text { mean }=3.35 \\
\text { median }=3\end{array}$ \\
\hline
\end{tabular}


Table 2.36

Quality/Availability of Colleges and Universities

\begin{tabular}{|c|c|c|}
\hline Poor (1) & $17.27 \%$ & \\
\hline Below Average (2) & $18.07 \%$ & \\
\hline Average (3) & $18.88 \%$ & \\
\hline Good (4) & $22.09 \%$ & \\
\hline \multirow[t]{2}{*}{ Excellent (5) } & $23.69 \%$ & \\
\hline & & $\begin{array}{r}\mathrm{n}=249 \\
\text { mean }=3.17 \\
\text { median }=3\end{array}$ \\
\hline
\end{tabular}

Table 2.37

Quality/Availability of Health Care

\begin{tabular}{|c|c|c|}
\hline Poor (1) & $6.37 \%$ & \\
\hline Below Average (2) & $14.34 \%$ & \\
\hline Average (3) & $26.69 \%$ & \\
\hline Good (4) & $28.29 \%$ & \\
\hline Excellent (5) & $24.30 \%$ & \\
\hline & & $\begin{array}{r}\mathrm{n}=256 \\
\text { mean }=3.5 \\
\text { median }=4\end{array}$ \\
\hline
\end{tabular}


Table 2.38

Arts and Cultural Opportunities

\begin{tabular}{|c|c|c|}
\hline Poor (1) & $4.37 \%$ & \\
\hline Below Average (2) & $8.73 \%$ & \\
\hline Average (3) & $21.43 \%$ & \\
\hline Good (4) & $32.14 \%$ & \\
\hline Excellent (5) & $33.33 \%$ & \\
\hline & & $\begin{array}{r}\mathrm{n}=252 \\
\text { mean }=3.81 \\
\text { median }=4\end{array}$ \\
\hline
\end{tabular}

Table 2.39

Pedestrian Safety

\begin{tabular}{|l|lr|}
\hline Poor (1) & $0.39 \%$ & \\
\hline Below Average (2) & $8.20 \%$ & \\
\hline Average (3) & $23.05 \%$ & \\
\hline Good (4) & $49.61 \%$ & $\mathrm{n}=256$ \\
\hline Excellent (5) & $18.75 \%$ & mean $=3.78$ \\
& & median $=4$ \\
\hline
\end{tabular}


Table 2.40

Safety from Crime

\begin{tabular}{|c|c|c|}
\hline Poor (1) & $0.39 \%$ & \\
\hline Below Average (2) & $4.69 \%$ & \\
\hline Average (3) & $19.14 \%$ & \\
\hline Good (4) & $47.27 \%$ & \\
\hline Excellent (5) & $28.52 \%$ & \\
\hline & & $\begin{array}{r}\mathrm{n}=256 \\
\text { mean }=3.99 \\
\text { median }=4\end{array}$ \\
\hline
\end{tabular}

Table 2.41

Employment Opportunities

\begin{tabular}{|c|c|c|}
\hline Poor (1) & $5.91 \%$ & \\
\hline Below Average (2) & $28.35 \%$ & \\
\hline Average (3) & $35.43 \%$ & \\
\hline Good (4) & $24.41 \%$ & \\
\hline \multirow[t]{2}{*}{ Excellent (5) } & $5.91 \%$ & \\
\hline & & $\begin{array}{r}\mathrm{n}=254 \\
\text { mean }=2.96 \\
\text { median }=3\end{array}$ \\
\hline
\end{tabular}


Table 2.42

Tolerance of Diversity

\begin{tabular}{|c|c|}
\hline Poor (1) & $0.39 \%$ \\
\hline Below Average (2) & $7.06 \%$ \\
\hline Average (3) & $32.16 \%$ \\
\hline Good (4) & $41.57 \%$ \\
\hline Excellent (5) & $18.82 \%$ \\
\hline
\end{tabular}

Table 2.43

Attractiveness of Downtown

\begin{tabular}{|c|c|}
\hline Poor (1) & $3.53 \%$ \\
\hline Below Average (2) & $12.94 \%$ \\
\hline Average (3) & $25.49 \%$ \\
\hline Good (4) & $34.90 \%$ \\
\hline Excellent (5) & $23.14 \%$ \\
\hline
\end{tabular}


Table 2.44

Parking

\begin{tabular}{|l|lr|}
\hline Poor (1) & $1.57 \%$ & \\
\hline Below Average (2) & $12.55 \%$ & \\
\hline Average (3) & $30.98 \%$ & \\
\hline Good (4) & $38.82 \%$ & $\mathrm{n}=255$ \\
\hline Excellent (5) & $16.08 \%$ & mean $=3.55$ \\
& & median $=4$ \\
\hline
\end{tabular}

Table 2.45

Quality/Availability of Parks and Greenspace

\begin{tabular}{|c|c|c|}
\hline Poor (1) & $2.75 \%$ & \\
\hline Below Average (2) & $14.90 \%$ & \\
\hline Average (3) & $25.88 \%$ & \\
\hline Good (4) & $31.76 \%$ & \\
\hline Excellent (5) & $24.71 \%$ & \\
\hline & & $\begin{array}{r}\mathrm{n}=255 \\
\text { mean }=3.61 \\
\text { median }=4\end{array}$ \\
\hline
\end{tabular}


Table 2.46

Quality/Availability of Hotels

\begin{tabular}{|c|c|c|}
\hline Poor (1) & $27.06 \%$ & \\
\hline Below Average (2) & $27.06 \%$ & \\
\hline Average (3) & $18.04 \%$ & \\
\hline Good (4) & $18.43 \%$ & \\
\hline \multirow[t]{2}{*}{ Excellent (5) } & $9.41 \%$ & \\
\hline & & $\begin{array}{r}\mathrm{n}=255 \\
\text { mean }=2.56 \\
\text { median }=2\end{array}$ \\
\hline
\end{tabular}

Table 2.47

Availability of Government Services

\begin{tabular}{|c|c|}
\hline Poor (1) & $0.79 \%$ \\
\hline Below Average (2) & $3.17 \%$ \\
\hline Average (3) & $20.63 \%$ \\
\hline Good (4) & $40.48 \%$ \\
\hline Excellent (5) & $34.92 \%$ \\
\hline
\end{tabular}


Table 2.48

Usage of Downtown during non-standard business hours

\begin{tabular}{|c|c|c|}
\hline Poor (1) & $12.50 \%$ & \\
\hline Below Average (2) & $30.86 \%$ & \\
\hline Average (3) & $22.27 \%$ & \\
\hline Good (4) & $19.92 \%$ & \\
\hline Excellent (5) & $14.45 \%$ & \\
\hline & & $\begin{array}{r}\mathrm{n}=256 \\
\text { mean }=2.93 \\
\text { median }=3\end{array}$ \\
\hline
\end{tabular}

Table 2.49

Ability to compete with shopping outside downtown

\begin{tabular}{|c|c|c|}
\hline Poor (1) & $19.92 \%$ & \\
\hline Below Average (2) & $35.16 \%$ & \\
\hline Average (3) & $27.73 \%$ & \\
\hline Good (4) & $12.11 \%$ & \\
\hline \multirow[t]{2}{*}{ Excellent (5) } & $5.08 \%$ & \\
\hline & & $\begin{array}{r}\mathrm{n}=256 \\
\text { mean }=2.47 \\
\text { median }=2\end{array}$ \\
\hline
\end{tabular}

Note that the ability to compete with shopping outside the city center ranks fairly low among policymakers. This measure competition should register as an important factor in how elites make an overall assessment of downtown (Walzer 
and Kline 2001), but it should be noted again that it may not be the most important factor impacting this rating (Wolman, et. al. 1994).

Table 2.50

Support for downtown from your state government

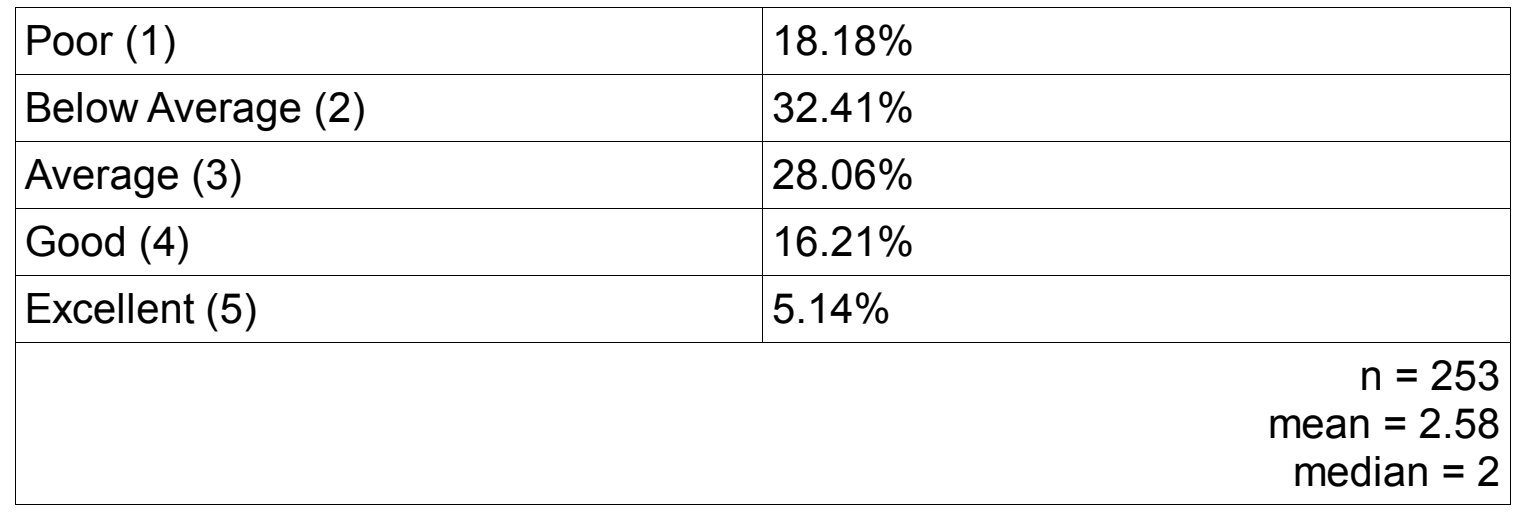

It would be interesting to look at the relationship between perceived support from the state government and grants from state and local government that went towards downtown. Table 2.51 reports a cross-tabulation of these figures.

Table 2.51

Cross-tabulation of State Support and State/Local Grants Received

\begin{tabular}{|c|c|c|c|c|c|}
\hline & \multicolumn{5}{|c|}{ Level of Perceived Support (from 1 - Poor to 5 - Excellent) } \\
\hline & $\mathbf{1}$ & $\mathbf{2}$ & $\mathbf{3}$ & $\mathbf{4}$ & $\mathbf{5}$ \\
\hline No Grants & 30 & 37 & 30 & 12 & 4 \\
\hline Grants & 26 & 45 & 40 & 29 & 9 \\
\hline \multicolumn{7}{|r}{} & & $\begin{array}{r}\text { chi }^{2}=\mathbf{1 2 . 9 0} \\
\mathbf{p}=\mathbf{0 . 0 1}\end{array}$ \\
\hline
\end{tabular}

It is somewhat evident that assessment of state support for grants is at least partially a factor of grant funding coming from the state government. The 
grant measure here does not give a perfect picture, however, because it includes local grants which may not involve the state government.

Table 2.52

Support for downtown from the federal government

\begin{tabular}{|c|c|}
\hline Poor (1) & $25.10 \%$ \\
\hline Below Average (2) & $33.47 \%$ \\
\hline Average (3) & $29.48 \%$ \\
\hline Good (4) & $8.37 \%$ \\
\hline Excellent (5) & $3.59 \%$ \\
\hline
\end{tabular}

As with state grants, it would be informative to examine the relationship between federal grants and the perception of support coming from the federal government from downtown. Table 2.53 reports those results below.

Table 2.53

Cross-tabulation of Federal Support and Federal Grants Received

\begin{tabular}{|c|c|c|c|c|c|}
\hline & \multicolumn{6}{|c|}{ Level of Perceived Support (from 1 - Poor to 5 - Excellent) } \\
\hline & $\mathbf{1}$ & $\mathbf{2}$ & $\mathbf{3}$ & $\mathbf{4}$ & $\mathbf{5}$ \\
\hline No Grants & 51 & 59 & 38 & 7 & 2 \\
\hline Grants & 12 & 25 & 35 & 14 & 7 \\
\hline \multicolumn{7}{|r}{} \\
\hline
\end{tabular}


Perceptions of the federal government show up here as even more influenced by the reception of federal grants by the community.

Table 2.54

Question 7: "Assuming things stay on the same course, what direction do you think your downtown is headed over the next 10 years?"

\begin{tabular}{|l|l|}
\hline A positive direction (3) & $78.91 \%$ \\
\hline It will stay the same (2) & $17.19 \%$ \\
\hline A negative direction (1) & $3.91 \%$ \\
\hline & \\
& \\
\hline
\end{tabular}

Respondents were overwhelmingly positive about the direction downtown is headed. Their optimism may largely be a function of their role as a political elite and the perception that they can make a contribution to the improvement of the city. Another important factor to this response was how they felt downtown was at the moment. Those pessimistic about the current state of the community were more likely to believe things could not be changed or that they would get worse. Table 2.55 demonstrates. 
Table 2.55

Cross-tabulation of Downtown and Future Direction

\begin{tabular}{|c|c|c|c|}
\hline & Future Direction of Downtown (1-Negative to 3 - Positive) \\
\hline $\begin{array}{c}\text { Overall } \\
\text { Downtown } \\
\text { Assessment }\end{array}$ & $\mathbf{1}$ & $\mathbf{2}$ & $\mathbf{3}$ \\
\hline Poor & 0 & 6 & 4 \\
\hline Below Average & 3 & 14 & 34 \\
\hline Average & 2 & 13 & 45 \\
\hline $\begin{array}{c}\text { Above } \\
\text { Average }\end{array}$ & 5 & 10 & 45 \\
\hline Excellent & 0 & 1 & 42 \\
\hline & & & $\mathbf{c h i}^{\mathbf{2}} \mathbf{3 0 . 3 4}$ \\
$\mathbf{p}=\mathbf{0 . 0 0}$
\end{tabular}

Table 2.56

Question 8: "What is the biggest challenge facing your downtown's development?"

\begin{tabular}{|l|l|}
\hline Quality of Life Issues & $17.97 \%$ \\
\hline $\begin{array}{l}\text { Lack of cooperation between public, private, and non-profit } \\
\text { groups }\end{array}$ & $15.93 \%$ \\
\hline Lack of adequate public policies/programs & $6.54 \%$ \\
\hline Lack of finances for development & $64.23 \%$ \\
\hline Failure of downtown business to compete in the marketplace & $30.61 \%$ \\
\hline Other & $0.00 \%$ \\
\hline \multicolumn{2}{|c|}{$\mathrm{n}=245$} \\
\hline
\end{tabular}


Note: These percentages do not add up to $100 \%$ because approximately half of all respondents chose more than one answer. The relationship between these problems and indicators of what affects downtowns will be considered in Chapter

3.

Failure of downtown to compete in the marketplace shows up as the single most important challenge facing local communities. This synchs with previous survey research which also found that to be the most important issue amongst local leaders (Walzer and Kline 2001). It should also be expected that it would become very important in any model of overall downtown success.

Table 2.57

Question 9: "Would you say your downtown is a good place to raise a family?"

\begin{tabular}{|l|l|}
\hline Yes $(1)$ & $66.80 \%$ \\
\hline No $(0)$ & $33.20 \%$ \\
\hline & \\
\hline
\end{tabular}

Because of the differentiation found here (there is not a 1 to 1 correlation between downtown evaluation and whether or not it would be a good place to raise a family), this question's interesting results can provide reason to include it in some of the later statistical models. It may also function as a proxy for quality of life variables. 


\section{Ranking of Quality of Life Issues Among Policymakers}

When respondents were asked to rank a large list of issues in their downtown from poor to excellent, several items emerged that were seen to be consistently below "average". These should be examined with more detail to see what quality of life issues could be major issues for downtowns around the United States.

Items with a mean ranking below "average", the mean ranking is presented in parenthesis out of 5 with a 3 being "average":

- Quality/Availability of Groceries (2.32)

- Quality/Availability of Shopping (2.92)

- Quality/Availability of Downtown Housing (2.74)

- Employment Opportunities (2.96)

- Quality/Availability of Hotels (2.56)

- Usage of downtown during non-standard business hours (2.93)

- Ability to compete with shopping outside downtown (2.47)

- Support for downtown from your state government (2.58)

- Support for downtown from the federal government (2.32) 
Also, many items were ranked as being consistently above "average":

- Quality/Availability of Restaurants (3.71)

- Quality/Availability of Public Transportation (3.37)

- Quality/Availability of Schools (3.35)

- Quality/Availability of Colleges and Universities (3.17)

- Quality/Availability of Health Care (3.5)

- Arts and Cultural Opportunities (3.81)

- Pedestrian Safety (3.78)

- Safety from Crime (3.99)

- Tolerance of Diversity (3.71)

- Attractiveness of Downtown (3.61)

- Parking (3.55)

- Quality/Availability of Parks and Greenspace (3.61)

- Availability of Government Services (4.06)

At first glance, it seems that on the surface respondents may have ranked items they felt responsible for as higher (e.g. availability of government services, safety from crime, etc.) and other things they felt were out of their control as much lower(e.g. ability of downtown to compete, support from state and federal government, etc.). That is not entirely true, however, with an examination of the whole. Notice, for instance, the high ranking of availability/quality of restaurants and the low ranking of quality/availability of housing. Housing would seem to be 
a larger policy problem for local officials than restaurants would be. Looking at the variation between items, it seems as though respondents really took their time and thought about responding with an answer that best reflected their perception of the situation in their communities.

Availability of government services would be expected to be high in a downtown area as well. The majority of cities in the United States have been built in the past with the intention that government will be located around the downtown. County courthouses, post offices, police stations, and other government offices have traditionally been located within the central business district and even the focal point of some towns and cities.

It seems somewhat concerning that some of the lowest ranked issues are some of the most important for quality of life. Quality and availability of groceries and housing are both some of the most basic necessities of life and both seem to be miserably inadequate according to the responses here. Employment opportunities are also ranked low, which indicates that finding a job within the downtown or central business district may be difficult. The results seem to indicate that downtowns have become locations for eating out and attending arts and cultural events, but not for actually living on a daily basis. Health care, on the other hand, shows a surprisingly high rating and warrants further investigation in the future. It may be that clinics and hospitals are often located downtown in small cities. 


\section{Chapter 3: A Model of Successful Downtowns}

\section{A Model of Downtown Self-Assessment}

Having established summary results for the survey instrument, it is now prudent to turn attention to modeling successful downtowns. Although it was noted that a slight amount of bias may cause policymakers to artificially inflate estimates of their city's quality, it does seem that respondents were fairly honest (considering about half of respondents ranked their city as average or less and only approximately $17 \%$ chose excellent). For the primary model constructed, then, it seems that self-assessment of downtown is a good choice as a dependent variable. It presents a straightforward question to policymakers that offers face validity in understanding overall downtown quality.

A few measures stood out in the literature as potential indicators of downtown success. Cooperation was mentioned in all types of literature as being extremely important. The survey instrument asks for a self-assessment of the level of cooperation between some of the key stakeholders in downtown. The quality of cooperation, after all, is a normative measure, so policymakers' own view points should honestly give at least a general idea of how well groups are working together. It can be included in the model of downtown success.

Zoning seemed to be the single most important policy decision tool available to local governments. Higher levels of mixed-use zoning allows for many of the quality of life issues (creative class, shopping, housing, etc.) to be 
stronger and, according to research, strengthens the business core of downtown. Out of the programs discussed, Main Street USA stood as the most common and highly praised organization that works to make downtown succeed. Where Main Street programs are located, we would expect a more robust city center. Local leaders consistently, both in this survey instrument and others, ranked competition from outside businesses as one of the biggest problems facing central business districts. A measure of how well downtowns were able to compete was included in the quality of life variables, and will be used as an independent variable. Finally, a question that has been used as an index of quality of life variables in prior research (Johnson and Rasker 1995) was also included. If an individual feels that a city is a "good place to raise a family", it seems evident they would feel the overall quality of life is good.

The emerging model looks like the following:

\section{Cooperation among policymakers + Amount of Mixed-Use Zoning + Active Main Street Program + Quality of Life (measured by Family Question) + Success or Failure of Downtown to Compete $=$ Overall Assessment of Downtown}

Using STATA, this model was tested using ordinal linear regression. The results appear in Table 3.1. 
Table 3.1: Ordinal Regression Model of Overall Self-Assessment of

Downtown

\begin{tabular}{|c|c|c|}
\hline Variable & Estimate & Sig. \\
\hline \multicolumn{3}{|l|}{ Threshold } \\
\hline Ovrdtown $=1.00$ & -6.25 & $.00^{* *}$ \\
\hline 2.00 & -4.47 & $.00^{* *}$ \\
\hline 3.00 & -3.37 & $.00^{* *}$ \\
\hline 4.00 & -1.594 & $.00^{* *}$ \\
\hline \multicolumn{3}{|l|}{ Location } \\
\hline cooperation $=1.00$ & -1.10 & .33 \\
\hline 2.00 & -1.81 & $.00^{* *}$ \\
\hline 3.00 & -1.20 & $.00^{* *}$ \\
\hline 4.00 & -.98 & $.00^{* *}$ \\
\hline Mixed Use $=1.00$ & -.66 & .14 \\
\hline 2.00 & -.42 & .07 \\
\hline 3.00 & -.43 & $.01^{* *}$ \\
\hline Mainstreet $=0.00$ & -.34 & $.02^{*}$ \\
\hline Good for Family=1.00 & -.33 & $.05^{\star}$ \\
\hline Ability to Compete $=1.00$ & -3.03 & $.00^{* *}$ \\
\hline 2.00 & -2.05 & $.00^{* *}$ \\
\hline 3.00 & -1.22 & $.01^{* *}$ \\
\hline 4.00 & -.36 & .44 \\
\hline & & $\begin{array}{r}\text { Pseudo } r^{2} \\
\text { Cox and Snell }=.60 \\
\text { Nagelkerke }=.63 \\
\text { McFadden }=.31 \\
{ }^{*} p<.05^{* *} p<.01\end{array}$ \\
\hline
\end{tabular}


Table 3.2 presents these results using ordinary least squares regression:

Table 3.2

Regression Model of Overall Self-Assessment of Downtown

\begin{tabular}{|l|l|l|l|}
\hline & Coefficient & $\mathrm{t}$ & $\mathrm{p}$ \\
\hline cooperation & .32 & 5.64 & $.00^{* *}$ \\
\hline mixed-use zoning & .14 & 2.2 & $.03^{*}$ \\
\hline $\begin{array}{l}\text { main street } \\
\text { program }\end{array}$ & .19 & 2.07 & $.04^{*}$ \\
\hline good for family & .22 & 2.05 & $.04^{*}$ \\
\hline ability to compete & .51 & 10.45 & $.00^{* *}$ \\
\hline & & $\begin{array}{r}\mathrm{n}=247 \\
\text { r-squared }=0.58\end{array}$ \\
& & & $\begin{array}{r}\text { adjusted r-squared }=0.58 \\
\text { * } \mathrm{p}<.05{ }^{* *} \mathrm{p}<.01\end{array}$ \\
\hline
\end{tabular}

Several factors make it more efficient to present the statistical analysis for the duration of this dissertation using ordinary least squares. While the assumption that the dependent variable is a scale variable is violated, there is a small sample size rendering the ordinal regression as more suspect. Also, coefficients are easier to interpret and discuss with the OLS model, not to mention that it provides a more concise way to present the results. Both methods were used on the data for each model, and the results are very similar for both methods.

This model turns out to be a strong predictor of healthy downtowns, evident both from the r-squared and from the individual variable significance. All the independent variables emerge as significant here. Starting with the most significant, competition, it seems that perceptions of how well a downtown is able 
to compete with outside forces are indeed very important. This variable speaks to the need to be prudent with indirect subsidies for businesses outside city centers if the goal is to create a successful central business district. It also may indicate that boundaries such as urban service boundaries or urban growth boundaries, at least in theory, might be good if implemented correctly.

Cooperation emerges as the second most significant variable in this model. That comes as expected because these coalitions can influence every program and policy implemented by a city. Without a healthy level of cooperation, revitalization and maintenance of downtown generally fails.

Mixed-use zoning, raising a family, and the presence of a Main Street program all show up near each other on the significance scale. They demonstrate the importance of programs, policies, and quality of life issues. Although they do not show the same level of significance as competition and cooperation, it is necessary to recall how those two variables can be strongly linked to policy decisions as well.

Theoretically it can be argued that this is the strongest model. It takes the most important policy decision (zoning), the most revered program (Main Street), an index of quality of life issues (family), a control for the amount of cooperation (which effects all efforts in downtown revitalization) and a level of free-market competition (which may also involve direct and indirect subsidies in a roundabout manner). 
Using only the single most prominent policy and program may seem odd at first, but in reality with the overwhelming number to choose from it seemed as though throwing many policies and programs into the model could cause a lot of interference, especially when the literature only strongly endorses mixed-use zoning and Main Street programs. All the other policies and programs discussed either had a lack of empirical support, had not been around long enough to be tested, or have demonstrated mixed results. This model offers a streamlined and robust statistical analysis of downtown development and has strong explanatory power.

Since the model matches up extremely well with the literature, it should also be examined how well it holds up to the problems and solutions that policymakers themselves believe are important. Table 2.56 in Chapter 2 gave a breakdown of the biggest challenge to downtown development according to respondents. It is reproduced here: 
Table 2.56

Question 8: "What is the biggest challenge facing your downtown's development?"

\begin{tabular}{|l|l|}
\hline Quality of Life Issues & $17.97 \%$ \\
\hline $\begin{array}{l}\text { Lack of cooperation between public, private, and non-profit } \\
\text { groups }\end{array}$ & $15.93 \%$ \\
\hline Lack of adequate public policies/programs & $6.54 \%$ \\
\hline Lack of finances for development & $64.23 \%$ \\
\hline Failure of downtown business to compete in the marketplace & $30.61 \%$ \\
\hline Other & $0.00 \%$ \\
\hline \multicolumn{2}{|c|}{$\mathrm{n}=245$} \\
\hline
\end{tabular}

Based solely on an analysis of the model, it is hard to make judgments about financial resources for development (although alternative models later in this chapter find little relationship between grants and successful downtowns, an indicator that perhaps policymakers put too much emphasis on finances and not on the other potential challenges.) Respondents do seem to have a good perception of the importance of competition and quality of life issues regarding successful downtowns.

Because cooperation was so significant to the model, actually turning out to be the second most significant indicator, it seems as though policymakers may undervalue how much coalitions mean to the status of downtown. They also seem to believe policies and programs are adequate to a large degree. This could be a function of believing they are doing all they can to help out the city through policymaking, but more likely it demonstrates a lack of understanding 
about how policies and programs can help shape competition among business, create successful coalitions, and bring money and other resources downtown. Overall it should be noted that despite these small incongruities, policymakers largely see eye to eye with the literature about problems and their beliefs hold up fairly well in the statistical analysis.

While this model seems to be the best fit for the theoretical frame, there are some objections and alternatives that can be considered. The following section will discuss what some of these alternative models are and how they relate to and sometimes strengthen the hypotheses laid out in Chapter 1.

\section{Quality of Life Models}

One possible critique was mentioned earlier in a theoretical framework. It could potentially be argued that quality of life variables are actually measuring the success of downtown; the two variables could be almost the same thing. If so, having a quality of life index could pose methodological problems. Table 3.3 presents the same model, excluding the family variable, so that the model looks as follows:

\section{Cooperation among policymakers + Amount of Mixed-Use Zoning + Active Main Street Program + Success or Failure of Downtown to Compete $=$ Overall Assessment of Downtown}


Table 3.3

Regression Model of Overall Self-Assessment without family variable

\begin{tabular}{|c|c|c|c|}
\hline & Coefficient & $\mathrm{t}$ & p \\
\hline cooperation & .34 & 6.07 & $.00^{* *}$ \\
\hline mixed-use zoning & .14 & 2.28 & $.02 *$ \\
\hline main street program & .20 & 2.12 & $.04 *$ \\
\hline ability to compete & .53 & 11.06 & $.00 * *$ \\
\hline & & & $\begin{aligned} & \mathrm{n}=251 \\
& \mathrm{r} \text {-squared }=0.57 \\
& \text { justed } \mathrm{r} \text {-squared }=0.56 \\
& * \mathrm{p}<.05 \quad * * \mathrm{p}<.01\end{aligned}$ \\
\hline
\end{tabular}

The model holds together quite well, even without the quality of life variables. Interestingly, removing these variables leaves a model that retains much of its strength empirically. The contention here is that part of the theoretical strength of the model is lost, however, making this secondary model less attractive.

Instead of using the question 9, "Would you say your downtown is a good place to raise a family?" for a quality of life index, it is also possible to create an index based off individual responses to the questions. The following index was created by the following formula that includes variables from question 6 (possibly imperfect because it does not have weights, but it is challenging to put a value on certain quality of life variables over others, and there is no real theoretical reason for doing so): 


\section{Groceries + Restaurants + Shopping + Housing + Transportation + \\ Schools + Colleges + Healthcare + Arts + Pedestrian Safety + Crime \\ Safety + Employment + Tolerance + Attractiveness + Parking + \\ Greenspace + Hotels + Government Services + Afterhours Usage}

Before looking at how this index works in the model, the way each of these variables correlates with overall assessment of downtown is important. It can help illustrate what quality of life variables are seemingly important to a selfassessment of downtown. 
Table 3.4

Quality of Life correlations with Overall Downtown Assessment

\begin{tabular}{|l|l|l|}
\hline Variable & Correlation & p \\
\hline groceries & 0.1 & .11 \\
\hline restaurants & 0.58 & .00 \\
\hline shopping & 0.64 & .00 \\
\hline housing & 0.45 & .00 \\
\hline transportation & 0.3 & .00 \\
\hline schools & 0.25 & .00 \\
\hline colleges & 0.34 & .00 \\
\hline healthcare & 0.31 & .00 \\
\hline arts & 0.53 & .00 \\
\hline pedestrian safety & 0.45 & .00 \\
\hline crime safety & 0.45 & .00 \\
\hline employment & 0.56 & .00 \\
\hline tolerance & 0.36 & .00 \\
\hline attractiveness & 0.74 & .00 \\
\hline parking & 0.35 & .00 \\
\hline greenspace & 0.37 & .00 \\
\hline hotels & 0.3 & .00 \\
\hline government services & 0.38 & .00 \\
\hline afterhours & 0.64 & .00 \\
\hline overall QoL Index & 0.73 & .00 \\
\hline
\end{tabular}

The most heavily correlated quality of life variable is attractiveness.

Obviously, aesthetic appeal and the look of a community is important to how individuals view their downtown. Attractiveness itself may be related to other 
qualities of cities as well. One could imagine that a beautiful city would have less abandoned buildings, trash on the streets, look and feel safer, and perhaps even have less of a problem with the homeless and other problems that plague some communities. This also backs up literature that deals with perceptions of downtown, and how a negative or positive view can influence where people live and shop.

Examining the other variables, we find that restaurants, shopping, employment and usage of downtown afterhours all have a correlation statistic over .5. This is not surprising, as so much discussion of downtown stability revolves around business and its success. Attitudes about restaurants and shopping are directly tied to competition from outside the central business district. Employment may target businesses that are outside of the retail sphere, such as government jobs, law offices, medical services, and other non-sales.

Afterhours had the high correlation of .64. That may indeed be support for mixed-use zoning, as many of those who take advantage of city centers after mainstream work is over live either in or near downtown areas. Arts and cultural resources can be tied to creative class literature as well. In summary, the quality of life variables that are closely tied to perceptions of downtown also lend credence to the literature on community development and design. In fact, the overall quality of life index correlates with overall downtown assessment at a .73 level indicating a strong relationship. Theoretically, it becomes a "chicken or the 
egg" discussion of which comes first and how they influence each other. It may not be completely possible to untangle that web.

One potentially helpful use for the quality of life index is to use it in the model of overall downtown success. Since the question about raising a family was a proxy for overall quality of life, it needs to be removed from the new model. Table 3.5 presents these results:

Table 3.5

Regression Model of Overall Downtown Self-Assessment with Quality of Life Index

\begin{tabular}{|c|c|c|c|}
\hline & Coefficient & $\mathrm{t}$ & $\mathrm{p}$ \\
\hline cooperation & .26 & 4.5 & $.00^{* *}$ \\
\hline mixed-use zoning & .09 & 1.44 & .15 \\
\hline main street program & .12 & 1.29 & .20 \\
\hline ability to compete & .30 & 5.09 & $.00^{* *}$ \\
\hline QoL Index & .04 & 6.33 & $.00^{* *}$ \\
\hline & & & $\begin{array}{r}\mathrm{n}=222 \\
\mathrm{r} \text {-squared }=.64 \\
\text { adjusted } \mathrm{r} \text {-squared }= \\
* \mathrm{p}<.05 \quad * * \mathrm{p}<.01\end{array}$ \\
\hline
\end{tabular}

This model retains significance in the strongest variables from the original. Here, cooperation and ability to compete in the marketplace are both highly significant. The quality of life index turns out to be slightly higher than both according to the t-test statistic. Mixed-use zoning and a Main Street program drop out of significance, and that observation must be dealt with. It could be argued that the reason for this loss is that the purpose of both these variables is 
to improve the quality of life in an area (including shopping, after hours usage, attractiveness, etc.) All of these are touted by the Main Street program as goals, and the mixed-use zoning literature indicates that limited zoning of downtown areas has a negative effect on business and the overall sustainability of central business districts. That may explain, at least in part, the lack of significance seen in this alternative model.

This model seems to have an overall stronger explanatory power than the original. Theoretically, however, the weakness that the quality of life index is not weighted poses a massive problem. Because there is no reliable and valid method of weighting these issues in an index, it does not seem feasible to use it in the model and think that the overall quality is better. Even with the higher $r-$ squared value, the original model should be given preference, as it has a better backing by the literature and prior research.

\section{Direction of Downtown}

One of the more intriguing questions posed by the survey instrument was "Assuming things stay on the same course, what direction do you think your downtown is headed over the next 10 years?" Again, respondents were overwhelmingly positive in regards to this question, but it warrants a further examination. As mentioned in Chapter 2, there is a strong relationship between the perceived future of cities with the current condition they are in. Modeling the future direction of downtown, Table 3.6 shows other variables that might be influential in making that assessment: 
Table 3.6

Regression Model of Direction Downtown is Heading

\begin{tabular}{|l|l|l|l|}
\hline & Coefficient & $\mathrm{t}$ & $\mathrm{p}$ \\
\hline cooperation & .17 & 4.66 & $.00^{* *}$ \\
\hline mixed-use zoning & .05 & 1.2 & .23 \\
\hline main street program & -.05 & -0.88 & .38 \\
\hline good for family & .19 & 2.72 & $.01^{* *}$ \\
\hline ability to compete & .02 & 0.5 & .62 \\
\hline \multicolumn{2}{r|}{$\begin{array}{r}\mathrm{n}=247 \\
\end{array}$} \\
$\begin{array}{r}\text { r-squared }=0.20 \\
\text { adjusted r-squared }=0.18 \\
* \mathrm{p}<.05 * * \mathrm{p}<.01\end{array}$ \\
\hline
\end{tabular}

Although this model does not have high explanatory power, it does present curious elements of the independent variables. The proxy for quality of life, "Would you say your downtown is a good place to raise a family?" and the variable about coalitions among key stakeholders present themselves as valuable indicators of the direction downtowns are heading. This makes sense, because places with a high quality of life and with support from many different groups would most likely harbor optimistic feelings among respondents. They know that the town has the infrastructure and backing of residents, business, and non-profit groups and that the potential exists to continue to revitalize and maintain cities.

At the same time, zoning policy, the existence of a main street program, and the ability for downtowns to compete with business outside the city center 
are all insignificant in this model. That may mean that policymakers see these issues as static rather than dynamic. If respondents did not foresee a major shift in these variables over the next ten years, they would be more likely to disregard them in an assessment of the future. It could also signal that policymakers do not weigh these issues as highly (low percentages of respondents said that programs and policies were the most important issue facing downtown). The ability for downtowns to compete with business outside town seems as though it would be significant in future developments, so the loss of significance here remains somewhat of an anomaly.

\section{Funding}

Respondents believed that funding was one of the most important issues facing downtown. The survey instrument did not ask any direct questions about financing downtown. It was believed that respondents might have different ideas about what classifies as downtown funding (streets, sidewalks, other infrastructure, fire protection, etc.) and that it would not be possible to get a reliable figure that would be easily interpreted and defined across the board. Also, because there are considerable size differences between a city with a population of 25,000 and one of 100,000 , a raw figure of dollars invested in downtown projects may not be useful.

The survey did, however, ask two useful questions related to funding. Officials were asked if they received any state or local grants in the past ten years in one policy sub-question, and if they had received any federal grants in 
another. These variables can be added to the overall satisfaction model to see if they were significant. Table 3.7 reports these findings.

Table 3.7

Regression Model of Overall Self-Assessment of Downtown with Grants

\begin{tabular}{|c|c|c|c|}
\hline & Coefficient & $\mathrm{t}$ & $\mathrm{p}$ \\
\hline cooperation & .34 & 5.69 & $.00 * *$ \\
\hline mixed-use zoning & .14 & 2.27 & $.02 *$ \\
\hline main street program & .20 & 2.11 & $.04 *$ \\
\hline good for family & .21 & 2.03 & $.04 *$ \\
\hline ability to compete & .50 & 10.16 & $.00 * *$ \\
\hline federal grants & .04 & 0.37 & .71 \\
\hline state grants & -.12 & -1.14 & .26 \\
\hline & & & $\begin{array}{r}\mathrm{n}=247 \\
\mathrm{r} \text {-squared }=.59 \\
\text { ljusted } \mathrm{r} \text {-squared }=.57 \\
* \mathrm{p}<.05 * * \mathrm{p}<.01\end{array}$ \\
\hline
\end{tabular}

The model continues to show strong results and the same significance amongst the key independent variables. State and federal grants, however, have show no significance whatsoever, and the direction of the coefficient with regards to state grants is actually in the wrong direction. Very little can actually be said about the results here. It could be argued that cities with more impoverished and lackluster downtowns actually apply for or receive grants at a higher rate, or that grants are poorly implemented. Regardless of the 
interpretation, these results may re-emphasize the fact that policymakers tend to falsely view funding as extraordinarily more important than other variables such as zoning or Main Street programs.

Programs and Policies

The model of overall downtown assessment utilizes one of the most important policies, zoning, and one of the most active programs, the Main Street, USA organization. It is worth exploring what other programs and policies likely affect cities. One way to look at policies is to create an index of them all and examine their effect in the model. The policies index was created by the following formula (remember, policies were ranked a "1" if they were present and a "0" if they were not):

Tax Increment Financing + Real Estate Tax Abatements + User Fees + Developer Fees + Tax Credits + Debt Financing + Formal Policy Encouraging Private Development + Use of Eminent Domain/Public Acquisition + Development Moratoria + Direct Subsidies for Businesses Downtown + Indirect Subsidies for Businesses Located Downtown + Public Policy for Managing Urban Growth + Urban Growth Boundaries + Urban Service Boundaries + Business Improvement Districts $=$ Policy Index

This method has several drawbacks. As with the quality of life index presented earlier, it runs the risk of not being able to distinguish which policies are more important than others. It also does not speak to how well policies are 
implemented or discrete differences between the way a policy like urban growth boundaries are established and enforced. Nevertheless, it does test a commonly held idea that the more government gets involved and tries to work out problems, the more successful downtown can be. Table 3.8 presents this model. Note that zoning policy is included separately because it is not on a binomial scale.

Table 3.8

Regression Model of Overall Self-Assessment of Downtown with Policy Index

\begin{tabular}{|c|c|c|c|}
\hline & Coefficient & $\mathrm{t}$ & $\mathrm{p}$ \\
\hline cooperation & .31 & 5.32 & $.00 * *$ \\
\hline mixed-use zoning & .13 & 2.13 & $.03^{*}$ \\
\hline main street program & .19 & 2.06 & $.04 *$ \\
\hline good for family & .22 & 2.09 & $.04 *$ \\
\hline ability to compete & .51 & 10.41 & $.00 * *$ \\
\hline Policy Index & .02 & 0.81 & .42 \\
\hline & & & $\begin{array}{r}\mathrm{n}=246 \\
\mathrm{r} \text {-squared }=.59 \\
\text { djusted } \mathrm{r} \text {-squared }=.58 \\
* \mathrm{p}<.05 \quad * * \mathrm{p}<.01\end{array}$ \\
\hline
\end{tabular}

We find that increasing the sheer number of policies does not hold up as significant. This is very possibly because of the limitations of the index, however, in separate models policies were introduced and tested separately and none were found to be individually significant. As mentioned before, this is probably a combination of the quality of policy and implementation, because success relies so heavily on many factors, and because some policies such as Tax Increment 
Financing districts may take extended periods of time to adequately assess.

Most policies other than zoning had no clear effect in the literature as well, or were thought to be testable only in the future.

Programs have also been extensively treated by development scholars.

They can be modeled in a similar fashion with a program index:

Main Street + Historical Societies + Community Development Corporations

Input into the model, the results are promising as represented in Table 3.9:

Table 3.9

Regression Model of Overall Downtown Self-Assessment with Program Index

\begin{tabular}{|c|c|c|c|}
\hline & Coefficient & $\mathrm{t}$ & $\mathrm{p}$ \\
\hline cooperation & .32 & 5.63 & $.00 * *$ \\
\hline mixed-use zoning & .13 & 2.11 & $.04 *$ \\
\hline good for family & .22 & 2.06 & $.04 *$ \\
\hline ability to compete & .51 & 10.43 & $.00 * *$ \\
\hline program index & .10 & 2.11 & $.04 *$ \\
\hline & & & $\begin{array}{r}\mathrm{n}=247 \\
\mathrm{r} \text {-squared }=.58 \\
\text { djusted } \mathrm{r} \text {-squared }=.58 \\
* \mathrm{p}<.05 \quad * * \mathrm{p}<.01\end{array}$ \\
\hline
\end{tabular}

Because the program index shows up as significant, it seemed prudent to break the elements down into separate variables, especially considering there were only three. 
Table 3.10

\section{Regression Model of Overall Self-Assessment of Downtown with Programs Separate}

\begin{tabular}{|c|c|c|c|}
\hline & Coefficient & $\mathrm{t}$ & $\mathrm{p}$ \\
\hline cooperation & .32 & 5.53 & $.00^{* *}$ \\
\hline mixed-use zoning & .13 & 2.09 & $.00^{* *}$ \\
\hline main street program & .17 & 1.77 & .07 \\
\hline historic society & .15 & 1.58 & .12 \\
\hline $\mathrm{CDC}$ & -.05 & -0.04 & .68 \\
\hline good for family & .22 & 2.11 & $.04 *$ \\
\hline ability to compete & .51 & 10.32 & $.00 * *$ \\
\hline & & & $\begin{array}{r}\mathrm{n}=247 \\
\mathrm{r} \text {-squared }=0.59 \\
\text { usted } \mathrm{r} \text {-squared }=0.58 \\
* \mathrm{p}<.05 \quad * * \mathrm{p}<.01\end{array}$ \\
\hline
\end{tabular}

Separating the programs out, we find that the Main Street Program was driving the significance in the overall model. The coefficient shows Community Development Corporations in a reverse, but insignificant direction. Historical societies do not appear important either. This could be anticipated based off the literature review. Both of these programs were thought to be variable based off how they were implemented, and in some cases, such as when a historical society restricts the types of housing or perhaps limits needed new development, they can have a negative impact on downtown. 
Finally, Table 3.11 presents a model with the program index and the policy index.

Table 3.11

Regression Model of Overall Downtown Self-Assessment with Program and Policy Index

\begin{tabular}{|l|l|l|l|}
\hline & Coefficient & $\mathrm{t}$ & $\mathrm{p}$ \\
\hline cooperation & .32 & 5.44 & $.00^{* *}$ \\
\hline mixed-use zoning & .13 & 2.06 & $.04^{*}$ \\
\hline good for family & .22 & 2.06 & $.04^{*}$ \\
\hline ability to compete & .51 & 10.36 & $.00^{* *}$ \\
\hline program index & .10 & 1.99 & $.05^{*}$ \\
\hline policy index & .01 & 0.49 & $\begin{array}{r}.63 \\
\text { r-squared }=.59 \\
\end{array}$ \\
& & & $\begin{array}{r}\mathrm{n}=246 \\
\text { adjusted r-squared }=.58 \\
* \mathrm{p}<.05 * * \mathrm{p}<.01\end{array}$ \\
\hline
\end{tabular}

Again, programs show significance and policies do not. 


\section{Chapter 4: Conclusions}

This dissertation set about defining several key hypotheses, drawing heavily on existing downtown development literature, as to what creates a strong and vital downtown. Using a national sample of cities and controlling for competing explanations of success, it presents current and substantial evidence for a model of self-assessments of downtown quality. Bringing this final model together, it was evident that cooperation among policymakers, the extent to which a downtown is zoned for mixed-uses, the existing quality of life, and the success or failure for downtown to compete with other areas surrounding the city are some of the key variables to predict successful city centers. It is important to discuss in some detail what these results might mean and turn them into practical steps and suggestions policymakers can take to improve downtowns.

Looking at each of the four hypotheses in turn, it is important to understand how each fared when tested by the primary model. It is also important to show how the findings tie back into the literature and prior findings on downtown development, adding important quantitative findings to a solid theoretical foundation. 
Hypothesis 1: Revitalization efforts that involve multiple stakeholders (business, private citizens, non-profit groups, local, state, and federal policymakers, etc.) will have a positive impact on downtowns.

Cooperation turned out to be the second strongest variable in terms of significance, as might be expected from the literature summary in Chapter 1 . It is obvious from the model revitalization efforts and successful downtowns hinge upon bringing stakeholders together and working with them to maintain and improve city centers. According to the model, the literature is correct in its understanding of the importance of this variable, and this hypothesis holds up to the test quite well.

Why is cooperation so important? First, it has been indicated that entrenched elites can cause the massive failure of revitalization efforts in communities (Flora 2003). By removing these barriers, it allows a smooth path towards a successful city defined by the involvement of long-standing traditional values and new ideas about the direction the city should pursue. A higher level of cooperation may also foster a sense of community by involving younger individuals such as that of the creative class, a group thought to have a tremendously positive affect on the growth of cities (Florida 2004, 2007). Involving local business leaders, non-profit groups, citizens, developers and policymakers together can have a number of other positive impacts on downtown as well. First, it can help establish a sense of community and 
perception that downtown is improving, giving the community a stake in the success or failure of revitalization efforts (McClure and Harand 2001). This can lead to more involvement in volunteer projects, a rise in the overall attitudes towards downtown, and on an even simple level, just the increase of business revenues and utilization of downtown by the residents themselves (Smith, et. al. 1996).

Cooperation amongst these groups can also lead to fundraising and the influx of funding and other resources to be used by downtown improvement projects (Smith et. al. 1996). All these elements of cooperation come together well to enhance the success of downtown and this is clearly evident in the model of overall downtown quality.

Hypothesis 2: Local policymakers' public policy decisions, including zoning, subsidization, and tax policy have an impact on the shape and success of downtowns.

As this hypothesis predicts, the amount of mixed-use zoning in a downtown area turns out to be significant and important in judging the success of downtowns when tested by this model. This can be a function of many factors. Mixed -use zoning has been shown to increase the revenues generated by downtowns by allowing residents to live, work and shop in the same area without having to commute to areas outside of downtown (Kottis and Kottis 1972, Levine 
2005, Burayidi 2001, Daniels 1995, Robertson 1995, and Florida 2004 and 2007). As Levine (2005) points out, restrictive zoning may also limit who is able to live downtown, affect the quality of housing available, and cause a loss of business when residents are forced out of housing in city centers.

The importance of competition also may weigh in on the importance of public policy decisions by local policymakers. This is the variable showing up with the highest significance level. Policy can heavily effect the quality of competition between downtown and areas outside the city center, including how policymakers enable business using tax credits, infrastructure, and revitalization programs in downtown or in the suburban fringe to compete with one another (Walzer and Kline 2001, Levine 2005, and Burayidi 2001). This significance level may also indicate that correctly implemented urban growth boundaries and urban service boundaries may actually help the success of downtowns by increasing their ability to compete (either by providing indirect subsidies to downtown business or limiting their use outside city centers).

Perhaps this hypothesis does fall somewhat short, however, when all the other policies and programs are examined in later models. Many have little or no significance when included, and perhaps that indicates that government policy that actually impacts downtown is confined to a smaller role than the literature leads one to believe.

One reason these other policies do not make a significant impact is that they could be overshadowed by the importance of other variables. When these 
are implemented without the proper amount of mixed-use zoning, a healthy ability for downtown to compete, and a lack of cooperation amongst stakeholders in downtown, they may not have much of an impact. It should not be understated, however, that the model indicates government does have an important policy role.

Hypothesis 3: Cities that have embraced and worked with federal and nonprofit groups and programs will see a noticeable impact on their downtown environments.

Main Street, the most prominent program currently working for downtowns, shows up as significant in the model. This makes logical sense because the Main Street program could be supposed to have better resources, a history to draw upon, and a focus on other important variables such as competition and cooperation among key stakeholders. Their public relations campaigns and focus on festivals and other events can raise the general perception of the quality of downtown. Main Street programs have been lauded by the literature as being the most well put together and tested programs in the country. They also have one of the longest histories of working for the success of downtowns in the modern era. It could also be argued that Main Street programs are sought out by already viable cities, or locate themselves in downtowns that already have the capacity to be successful. 
As with government policies, the lack of other programs showing up as significant in later models may indicate that other programs have less of a role than might be thought otherwise. Overall, however, the model does show that programs can have a positive impact on downtown, and perhaps the Main Street model can be a starting point for future programs to develop from.

Hypothesis 4: Cities that have higher quality of life variables will have more successful downtowns.

The survey item about raising a family, when included in the statistical model, indicates that quality of life variables are important to assessments of downtown success. This variable most likely taps into many aspects of quality of life, including schools, safety, cultural opportunities, and other quality of life issues that face cities (Johnson and Rasker 1995). The relationship here is not simple by any means, and while it could be argued that quality of life and "success" of downtowns is the same thing, the statistical models showed that there are a combination of economic and social variables that make up the perceived quality of downtown among policymakers.

\section{Limitations and Future Research}

The survey instrument has a few limitations that should be addressed in future downtown development research. First, it has no adequate way to 
measure and test funding and its influence on quality of city centers in a comprehensive way. Secondly, it is possible that policymakers have some level of bias in their responses. The survey could be supplemented by surveys of residents and other stakeholders, especially with regards to cooperation and the quality of downtown. They may not be as familiar with minute policy angles probed by the instrument.

It is important for further research into the role of policy. Is there a way to separate out policy from the other variables in a way that, controlling for all other factors, it could be determined that policies such as TIF districts and tax credits have a significant impact on the quality of downtown? Once the proper cooperation and zoning has been established, many other policies may make an important contribution to downtown.

This survey may also be used to test more rural towns and large metropolitan cities. It would be interesting to compare the differences and similarities that were found.

Variables like cooperation are, in synch with the literature, found to be extremely important to downtown success. It could be clarified further, however, exactly what is important about that cooperation. Does it lead to more economic benefits for the city, or is it simply a matter of overcoming entrenched elites? Future studies could break cooperation (and perhaps some other variables) into its component parts and see how it holds up after being separated. This could 
lead to even more practical advice for policymakers and lead to stronger cities across the board.

Quality of life variables need to be thoroughly analyzed in future research. The relationship between walkability, living downtown, public transportation, social capital, and viable downtowns is an issue with much that remains to be examined.

\section{Practical Implications}

There are several practical implications for policymakers and other stakeholders that can be drawn from the conclusions found in this research. First, cities should do everything within their means to foster a sense of cooperation and coalitions among the community as a whole. Perhaps by starting with the suggestions of Flora (2003), policymakers can make a start towards bringing everyone together to work towards a successful downtown. Analyzing policymakers feelings about problems facing their communities, it was clear in Table 2.56 that they clearly underestimated the importance of good cooperation and its impact on their downtowns.

Local officials should closely examine their ideas about competition as well as direct and indirect subsidies. The survey findings reveal a disconnect between the amount of subsidization policymakers seem to see themselves responsible for and the amount the literature contends they are in control of. It may also be worth examining the role of government in fostering healthy competition between downtown and outlying areas. 
The question also arises whether government is creating a market inefficiency by helping downtowns (one which may have negative consequences in the long-term) or if they are simply balancing an already unfair level of competition that has been artificially created through other government action. Levels of government above the municipality can also consider their role in subsidizing business outside downtown. The debate over the legitimacy of government intervention in these sectors is largely outside the scope of this research and a question for political theory, however it does seem evident that either acting directly on downtown or ceasing to give suburban areas an unfair competitive advantage would cause an improvement in the status of our nation's downtowns.

The model indicates that policymakers would serve their communities well by discussing the possibility of removing the majority of zoning restrictions in downtown areas. Again, this opens up the ability for city centers to provide a wide variety of activities and businesses, not to mention allowing residents to move into downtown and boost its productivity (Levine 2005).

The recruitment of a Main Street program or at the very least implementing parts of the "Four-Point Main Street Approach" would seem to be a good step for improving downtowns. The side benefits of increased cooperation and a competitive business structure would also influence other important variables in the model. 
All these suggestions could lead to a better quality of life within cities. This would foster an environment better suited to raise families, and increase the success of downtown. Some of these ideas may be harder to implement than others. The improvement of cooperation and coordination of stakeholders or recruiting a Main Street program to a struggling city, for instance, would most likely be harder to achieve than deregulating mixed-uses in downtowns. Each step is important, however, and can have larger repercussions on long-term success.

Finally, it could be suggested by the findings here that policymakers who have exhausted their efforts at finding funding for downtown projects should move on to other policy angles they may have more control over. Funding is not the end-all of downtown revitalization, and the conclusions reached by this survey analysis show that there are many other ways for stakeholders to influence the overall success of downtown. An overwhelming $64 \%$ of policymakers felt funding was the biggest issue facing them (Table 2.56), and this indicates they may need to be aware of these other solutions and potential avenues to proceed by.

\section{Summary}

This model demonstrates the importance of public policy, programs, quality of life, cooperation, and the ability for downtown business to compete. These are the key elements that have been suggested as the most important by scholars of community revitalization over the last half century. 
The four hypotheses hold up very well in the model. The variables selected to represent them in the survey instrument show up as strong predictors of downtown success. While the programs and policies hypotheses show limitations, they do retain importance and strength with a bit of fine tuning. Obviously programs, policies, cooperation, and quality of life - the four main findings of evaluation literature up to this point - do hold up well in a more empirical examination.

This dissertation presents one of the most extensive and empirical looks at what actually influences downtown success. It successfully brings together all the elements that literature has assumed to be important and influential on having a vibrant city center and shows that they hold up well when tested quantitatively. The variables that have been discussed as the most important mixed-use zoning, cooperation with stakeholders, quality of life, a Main Street program, and competition with business outside the city are all significant in the final model.

Policymakers should focus on these issues when trying to maintain and improve their downtowns. While the lack of funding may always be an issue cities will probably always believe that they need more money - these policies and programs can be viable and important ways for policymakers to improve their downtowns, especially mixed-use zoning. Overall, downtown development may be heavily influenced by a few simple variables presented by the model rather than a complex web of decisions and funding issues. 
The contribution to the field of downtown revitalization here could be quite important. Competing theories that have been discussed and debated heavily over the past 20 years have been successfully combined into a theoretical construct that holds up well to empirical examination. The practical implications for policymakers and other stakeholders in communities are quite strong and are feasible to implement. The model presented here promises an efficient and grounded first-step towards successful downtowns. 


\section{Bibliography}

"The Creative City: Power for the New Economy." Partners for Livable Communities, 2000.

"Development and Revitalization of the Fifth and Forbes Area of Downtown Pittsburgh. Final Report Prepared for the Plan C Taskforce." H.I. Inc., 2002.

"Progress in Pennsylvania Downtowns." Center for Rural Pennsylvania, 2004. Alexander, C., S. Ishikawa, and M. Silverstein. "A Pattern Language." New York (1977).

Barber, B. R. Strong Democracy: Participatory Politics for a New Age: University of California Press, 2004.

Bengston, D. N., J. O. Fletcher, and K. C. Nelson. "Public Policies for Managing Urban Growth and Protecting Open Space: Policy Instruments and Lessons Learned in the United States." Landscape and Urban Planning 69, no. 2-3 (2004): 271-86.

Birch, Eugenie Ladner. "Having a Longer View on Downtown Living." Journal of the American Planning Association 68, no. 1 (2002): 5-21.

Breen, A., D. Rigby, D. C. Norris, and C. Norris. Waterfronts: Cities Reclaim Their Edge: McGraw-Hill, New York, 1994.

Brueckner, J. K. "Urban Sprawl: Diagnosis and Remedies." International Regional Science Review 23, no. 2 (2000): 160.

Burayidi, M. A. Downtowns: Revitalizing the Centers of Small Urban Communities: Routledge, 2001.

Burayidi, M.A. "Is Tax Increment Financing an Effective Development Tool?" Paper presented at the $40^{\text {th }}$ Annual Urban Affairs Association Conference. Honolulu, HI. 2010.

Catanese, A. J., and W. P. Farmer. Personality, Politics, and Planning: How City Planners Work: Sage Publications (CA), 1978.

Collins, R. C., E. B. Waters, and A. B. Dotson. America's Downtowns: Growth, Politics and Preservation: Wiley, 1995.

Crowley, G. J. The Politics of Place: Contentious Urban Redevelopment in Pittsburgh: University of Pittsburgh Press, 2005.

Curry, T. J., K. P. Schwirian, and R. Woldoff. High Stakes: Big Time Sports and Downtown Redevelopment: Ohio State University Press, 2004.

Daniels, T. "Smart Growth: A New American Approach to Regional Planning." Planning Practice and Research 16, no. 3 (2001): 271-79.

Daniels, T. L., J. W. Keller, and M. B. Lapping. The Small Town Planning Handbook: Amer Planning Assn, 1995.

Downs, A. Neighborhoods and Urban Development: Brookings Institution Press, 1981.

Duany, A., E. Plater-Zyberk, and J. Speck. Suburban Nation: The Rise of Sprawl and the Decline of the American Dream: North Point Press, 2000. 
Ehrenhalt, A. "Return to Main Street." Governing 9 (1996): 18-27.

Elmer, Joann C. "Loss of State Manufacturing Jobs Follows National Trend." State Journal, Monday, December 212001.

Farst, D. "Perceptions toward Downtown: Surveying City Managers in Smaller Texas Towns." Applied Research Projects (2003).

Faulk, D. "The Process and Practice of Downtown Revitalization." Review of Policy Research 23, no. 2 (2006): 625-45.

Ferguson, R. F., and W. T. Dickens. "Urban Problems and Community Development." The Social Science Journal 37, no. 2 (2000): 317-20.

Fernandez, B. "Wal-Mart Received Some \$1 Billion in Local, State Subsidies over Past 20 Years." Knight Ridder Tribune Business News (2004): 1.

Filion, P., and K. Hammond. "The Failure of Shopping Malls as a Tool of Downtown Revitalization in Mid-Size Urban Areas." PLAN CANADA 46, no. 4 (2006): 49.

. "The Failure of Shopping Malls as a Tool of Downtown Revitalization in Mid-Size Urban Areas." PLAN CANADA 46, no. 4 (2006): 49.

Flora, C. B. "Innovations in Community Development." Rural Development News (1997): 9.

. Rural Communities: Legacy and Change: Westview Press, 2003.

Florida, R. The Flight of the Creative Class: The New Global Competition for Talent: Collins, 2007.

- The Rise of the Creative Class: And How It's Transforming Work, Leisure, Community and Everyday Life: Basic Books, 2004.

Fogelson, R. M. Downtown: Its Rise and Fall, 1880-1950: Yale University Press, 2001.

Folz, D. H., and P. E. French. Managing America's Small Communities: People, Politics, and Performance: Rowman \& Littlefield Pub Inc, 2005.

Ford, L. R. America's New Downtowns: Revitalization or Reinvention?: Johns Hopkins University Press, 2003.

Fox, R., and S. Treuhaft. "Shared Prosperity, Stronger Regions: An Agenda for Rebuilding America's Older Core Cities,." Restoring Prosperity: The State Role in Revitalizing America's Older Industrial Cities (2005).

Francaviglia, R. V. Main Street Revisited: Time, Space, and Image Building in Small-Town America: University of lowa Press, 1996.

Franzese, P. L. "A Comparative Analysis of Downtown Revitalization Efforts in Three North Carolina Communities." The University of North Carolina, 2008.

Frieden, B. J., and L. B. Sagalyn. Downtown, Inc.: How America Rebuilds Cities: MIT Press, 1991.

Friedman, J. J. "Variations in the Level of Central Business District Retail Activity among Large Us Cities: 1954 and 1967." Land Economics 49, no. 3 (1973): 326-35. 
Gordon, P., and H. W. Richardson. "Are Compact Cities a Desirable Planning Goal?" Journal of the American Planning Association 63, no. 1 (1997): 95106.

Gotham, K. F. "A City without Slums: Urban Renewal, Public Housing, and Downtown Revitalization in Kansas City, Missouri." The American Journal of Economics and Sociology 60, no. 1 (2001): 285-316.

Grasso, P. G., and M. L. Westcott. "A Framework for Evaluating Housing and Community Development Partnership Projects." Public Administration Review (1992): 40-46.

Grisham, V. L., and W. F. Winter. Tupelo: The Evolution of a Community: Kettering Foundation Press, 1999.

Gutfreund, O. D. Twentieth Century Sprawl: Highways and the Reshaping of the American Landscape: Oxford University Press, USA, 2004.

Handy, S. "Smart Growth and the Transportation-Land Use Connection: What Does the Research Tell Us?" International Regional Science Review 28, no. 2 (2005): 146.

Hanham, Alison, Kate Burbank, Rick Moorefield, Bob Knight, Jeff Himes, and Paul Martin. "The Vitality of West Virginia's Downtowns." West Virginia University Extension Service, 2006.

Hardt, M. D. "The Emergence of a Competitive Core: Bifurcation Dynamics in Billings, Montana." In Downtowns: Revitalizing the Centers of Small Urban Communities, edited by Michael Burayidi: Routledge, 2001.

Hayden, D., and J. Wark. A Field Guide to Sprawl: WW Norton \& Company, 2004.

Hechesky, L. "Return to Main Street: An Assessment of the Main Street Revitalization Program." Marshall University, 2005.

Holcombe, R. G. Public Policy and the Quality of Life: Market Incentives Versus Government Planning: Greenwood Press, 1995.

Holtkamp, J., D. Otto, and N. Mahmood. "Economic Development Effectiveness of Multicommunity Development Organizations." Journal of the Community Development Society 28, no. 2 (1997): 242-56.

Houston Jr, L. O. "From Street to Mall and Back Again." Planning 56, no. 6 (1990).

Isenberg, A. Downtown America: University of Chicago Press, 2004.

Jackson, K. "Crabgrass Frontier: The Suburbanization of America." New York: Oxford University Press, 1985.

Johnson, J. D., and R. Rasker. "The Role of Economic and Quality of Life Values in Rural Business Location." Journal of Rural Studies 11, no. 4 (1995): 405-16.

Johnson, Nancy F. "An Overview of Current Downtown Revitalization Literature and Practices and the Hamilton Context." Hamilton: Hamilton Community Foundation, 2008.

Jossi, F. "Small Town Survival Strategies." Planning 63, no. 10 (1997). 
Kelbaugh, D. Repairing the American Metropolis: Common Place Revisited: University of Washington Press, 2002.

Kemp, R. L. Main Street Renewal: A Handbook for Citizens and Public Officials: McFarland \& Co Inc Pub, 2000.

Kottis, G. C., and A. Kottis. "A Statistical Exploration of Some Factors Responsible for Decline of the Central Business District." Land Economics 48, no. 2 (1972): 169-73.

Leinberger, C. B., Policy Center on Urban and Metropolitan, and Institution Brookings. Turning around Downtown: Twelve Steps to Revitalization: Brookings Institution Center on Urban and Metropolitan Policy, 2005.

Levine, J. Zoned Out: Regulation, Markets, and Choices in Transportation and Metropolitan Land-Use: Resources for the Future, 2005.

Listokin, D., B. Listokin, and M. Lahr. "The Contributions of Historic Preservation to Housing and Economic Development." HOUSING POLICY DEBATEWASHINGTON- 9 (1998): 431-78.

Loescher, Doug. "2009 National State of Main Street Report." 2009.

Mattera, P., and A. Purinton. "Shopping for Subsidies: How Wal-Mart Uses Taxpayer Money to Finance Its Never-Ending Growth." Good Jobs First (2004): 1-64.

Mattson, G. A. Small Towns, Sprawl, and the Politics of Policy Choices: The Florida Experience: University Press of America, 2003.

Maurrasse, David. "City Anchors: Leveraging Anchor Institutions for Urban Success"." CEOs for Cities, 2007.

McClure, K. "Managing the Growth of Retail Space." In Downtowns: Revitalizing the Centers of Small Urban Communities, edited by Michael Burayidi: Routledge, 2001.

McClure, Wendy, and Fred A. Hurand. "Re-Engaging the Public in the Art of Community Place Making." In Downtowns: Revitalizing the Centers of Small Urban Communities, edited by Michael Burayidi: Routledge, 2001.

Milder, N. D. Niche Strategies for Downtown Revitalization: A Hands-on Guide to Developing, Strengthening, and Marketing Niches: Downtown Research \& Development, 1997.

Mitchell, J. "Business Improvement Districts and The" New" Revitalization of Downtown." Economic Development Quarterly 15, no. 2 (2001): 115.

Moe, R., and C. Wilkie. Changing Places: Rebuilding Community in the Age of Sprawl: Henry Holt \& Co., 1997.

Noyes, Pat. "Local Government's Role in Downtown Revitalization: Clearing up Misconceptions." Main Street News, April 1989.

Orr, M., and D. M. West. "Citizens'views on Urban Revitalization: The Case of Providence, Rhode Island." Urban Affairs Review 37, no. 3 (2002): 397.

Palma, D., and D. Hyett. "Born Again: Downtown Revivals Offer Salvation for Cities." American City and Country 1, no. 12 (1997): 8.

Paradis, T. W. "The Small Town Growth Machine-Making the Commercial Strip Work for Downtown Redevelopment in Pontiac." Illinois, 1998. 
Peck, J. "Struggling with the Creative Class." International Journal of Urban and Regional Research 29, no. 4 (2005): 740-70.

Pelissero, J. P. Cities, Politics, and Policy: A Comparative Analysis: Cq Pr, 2003.

Persky, J., and H. Kurban. "Do Federal Funds Better Support Cities or Suburbs?" Research Paper. Brookings Institute. 2001.

Pittari, Jeremy. "City Officials, Employees Get a Look at Downtown Revitalization Plans." Picayune Times, February 52009.

Porter, M. E., Administration Graduate School of Business, and University Harvard. "The Competitive Advantage of the Inner City." Harvard Business Review 73 (1995): 55-55.

Robertson, K. "Downtown Development Principles for Small Cities." In Downtowns: Revitalizing the Centers of Small Urban Communities, edited by Michael Burayidi: Routledge, 2001.

Robertson, Kent. "Rural Downtown Development: Guiding Principles for Small Cities." Rural Research Report 17, no. 3 (2006).

Robertson, K. A. "Can Small-City Downtowns Remain Viable?" Journal of the American Planning Association 65, no. 3 (1999): 270-83.

_. "Downtown Redevelopment Strategies in the United States: An End-ofthe-Century Assessment." Journal of the American Planning Association 61, no. 4 (1995): 429-37.

_. "Downtown Retail Revitalization: A Review of American Development Strategies." Planning Perspectives 12, no. 4 (1997): 383-401.

_ . "Pedestrianization Strategies for Downtown Planners: Skywalks Versus Pedestrian Malls." Journal of the American Planning Association 59, no. 3 (1993): 361-70.

Rypkema, D. D. "The Importance of Downtown in the 21st Century." Journal of the American Planning Association 69, no. 1 (2003): 9-15.

Sakamoto, N. "Small Town Downtown Revitalization: A Case Study of the Main Street of Elkins, West Virginia." University of New Orleans, 1995.

Sanders, H. T. "The Politics of Development in Middle-Sized Cities: Getting from New Haven to Kalamazoo." The politics of urban development. Lawrence: University Press of Kansas (1987).

Service, WVU Extension. "Checking the Pulse of West Virginia's Downtowns." 2008.

Shoup, D.C. "The High Cost of Free Parking." Journal of Planning Education and Research 17 (1997): 3-20.

Skogan, W. "Fear of Crime and Neighborhood Change." Crime and Justice (1986): 203-29.

Smith, K., K. Joncas, and B. Parrish. Revitalizing Downtown: National Main Street Center, National Trust for Historic Preservation, 1996.

Sobel, R. S., and A. M. Dean. "Has Wal-Mart Buried Mom and Pop?: The Impact of Wal-Mart on Self-Employment and Small Establishments in the United States." Economic Inquiry, no. 0 (2007). 
Stitt, B. "The Lies of Downtown: A Look at the Myths That Keep Downtowns from Engaging in Effective Revitalization." Small Town (1996): 18-25.

View, L. "Having a Longer View on Downtown Living." Journal of the American Planning Association 68, no. 1 (2002).

Wagner, F. W., T. E. Joder, and A. J. Mumphrey. Urban Revitalization: Policies and Programs: Sage Pubns, 1995.

Walzer, N., and S. Kline. "An Evaluation of Approaches to Downtown Economic Revitalization." In Downtowns: Revitalizing the Centers of Small Urban Communities, edited by Michael Burayidi: Routledge, 2001.

West, D. M., and M. Orr. "Downtown Malls as Engines of Economic Development, Community Spirit, and Political Capital." Economic Development Quarterly 17, no. 2 (2003): 193.

Wolman, H. L., and C. Ford. "Evaluating the Success of Urban Success Stories." Urban Studies 31, no. 6 (1994): 835. 


\section{Appendix I: Survey Instrument and Cover Letter}


Dear Community Leader:

Attached is a survey to examine how you feel about various issues related to your community's downtown or central business district. We would like you to pleage fill out this stervey (it is very short) and return it to us in the enclosed self-addressed stamped envelope. Your responses are valuable and should only take you about 5 to 10 minutes.

Please understand that your answers will be totally anonymous. You are asked not to include your name and address on the survey. Please also understand you are under no obligation to answer every question. Your participation is completely voluntary. Only group responses will be reported. Please return your survey in the envelope included. The postage has been pre-paid.

This is a research study being conducted by the Institute for Public Affeirs at West Virginia University to help understand downtown development and what programs and policies are beneficial to communities. Thomas K. Bias is a Ph.D. Candidate in the Department of Political science at West Virginia University and this survey is also an clement of his dissertation rescareh in order to meet his degree requirement5. West Virginia University's institutional review board's acknowledgment of this study is on file. It you have any questions uhout this study, please contact Thomas K. Bias at 304-2933811 extension 5295 .

We would be most pleased if you could return the survey within a weck or so. Your coopcration with this research is extremely important and hopefully beneficial for communities including yours across the nation.

Sincerely,

Dr. Rohert Duval, Ph.D

Acting Directo:

Institute for Public Affairs

West Virginia University 
Please answer the following questions by checking your answer or writing in the space provided. Thank you again for taking the time to respond to this survey.

1. Does your city have an officially defined downtown (or central business district)?

$\square$ Yes

$\square$ No:

If no, is there a general area considered the downtown (or central business district) by yourself or your community? $\square$ Yes $\square$ No

2. How much of your downtown is zoned for mixed uses (some combination of residential, commercial, office, institutional, or other land uses)?

$\square$ None

$\square$ A little

$\square$ A lot

口All

3. Overall, how would you rate your downtown? $\square$ Poor

$\square$ Below Average

$\square$ Average

$\square$ Good

$\square$ Excellent

4. How well would you say that the general public, business owners, non-profit groups, and policy makers work together to improve or maintain your downtown?

口Poor

$\square$ Below Average

$\square$ Average

$\square$ Good

口Excellent

5. Which of the following programs/policies are, or have been active in the last ten years in your downtown (or central business district)? Please select all that apply.

$\square T a x$ Increment Financing (TIFs)

$\square$ Real Estate Tax Abatements

पUser Fees

DDeveloper Fees

口Tax Credits

$\square$ Debt Financing

$\square$ Main Street Program

DFormal policy encouraging private development

口Federal Grants to fund downtown development

$\square$ State/Local Grants to fund downtown development

$\square$ City sponsored festivals/activities/events UUse of eminent domain/public acquisition

口Development moratoria

口other (Please List): $\square$ Non-Profit Grants to fund downtown development

$\square$ Historic Society/Trust Program

$\square$ Direct Subsidies for businesses located downtown

IIndirect Subsidies (roads, sewage, water, etc.)

for businesses located downtown

$\square$ Direct Subsidies for businesses located outside downtown

$\square$ Indirect Subsidies (roads, sewage, water, etc.)

for businesses located outside downtown

$\square$ Public policies for managing urban growth

UUrban Growth Boundaries

पUrban Service Boundaries 


\begin{tabular}{|c|c|c|c|c|c|}
\hline \multicolumn{6}{|c|}{$\begin{array}{l}\text { How would you rate the following in your downtown/central business district? Please select the } \\
\text { appropriate box to rate each of the issues below: }\end{array}$} \\
\hline & Poor & Below Average & Average & Good & Excellent \\
\hline Quality/Availability of Groceries & $\square$ & $\square$ & $\square$ & $\square$ & $\square$ \\
\hline $\begin{array}{l}\text { Quality/Availability of Restaurants } \\
\text { or Cafés }\end{array}$ & $\square$ & $\square$ & $\square$ & $\square$ & $\square$ \\
\hline Quality/Availability of Shopping & $\square$ & $\square$ & $\square$ & $\square$ & $\square$ \\
\hline $\begin{array}{l}\text { Quality/Availability of Downtown } \\
\text { Housing }\end{array}$ & $\square$ & $\square$ & $\square$ & $\square$ & $\square$ \\
\hline $\begin{array}{l}\text { Quality/Availability of Public } \\
\text { Transportation }\end{array}$ & $\square$ & $\square$ & $\square$ & $\square$ & $\square$ \\
\hline Quality/Availability of Schools & $\square$ & $\square$ & $\square$ & $\square$ & $\square$ \\
\hline $\begin{array}{l}\text { Quality/Availability of Colleges and } \\
\text { Universities }\end{array}$ & $\square$ & $\square$ & $\square$ & $\square$ & $\square$ \\
\hline Quality/Availability of Health Care & $\square$ & $\square$ & $\square$ & $\square$ & $\square$ \\
\hline Arts and Cultural Opportunities & $\square$ & $\square$ & $\square$ & $\square$ & $\square$ \\
\hline Pedestrian Safety & $\square$ & $\square$ & $\square$ & $\square$ & $\square$ \\
\hline Safety from Crime & $\square$ & $\square$ & $\square$ & $\square$ & $\square$ \\
\hline Employment Opportunities & $\square$ & $\square$ & $\square$ & $\square$ & $\square$ \\
\hline Tolerance of Diversity & $\square$ & $\square$ & $\square$ & $\square$ & $\square$ \\
\hline Attractiveness of Downtown & $\square$ & $\square$ & $\square$ & $\square$ & $\square$ \\
\hline Parking & $\square$ & $\square$ & $\square$ & $\square$ & $\square$ \\
\hline $\begin{array}{l}\text { Quality/Availability of Parks and } \\
\text { Greenspace }\end{array}$ & $\square$ & $\square$ & $\square$ & $\square$ & $\square$ \\
\hline Quality/Availability of Hotels & $\square$ & $\square$ & $\square$ & $\square$ & $\square$ \\
\hline Availability of Government Services & $\square$ & $\square$ & $\square$ & $\square$ & $\square$ \\
\hline $\begin{array}{l}\text { Usage of Downtown during } \\
\text { non-standard business hours }\end{array}$ & $\square$ & $\square$ & $\square$ & $\square$ & $\square$ \\
\hline $\begin{array}{l}\text { Ability to compete with shopping } \\
\text { outside downtown }\end{array}$ & $\square$ & $\square$ & $\square$ & $\square$ & $\square$ \\
\hline $\begin{array}{l}\text { Support for downtown from your } \\
\text { state government }\end{array}$ & $\square$ & $\square$ & $\square$ & $\square$ & $\square$ \\
\hline $\begin{array}{l}\text { Support for downtown from the } \\
\text { federal government }\end{array}$ & $\square$ & $\square$ & $\square$ & $\square$ & $\square$ \\
\hline
\end{tabular}

7. Assuming things stay on the same course, what direction do you think your downtown is headed in over the next 10 years?

$\square$ A positive direction

DIt will stay about the same

$\square$ A negative direction

9. Would you say your downtown is a good place to raise a family?

$\square$ Yes

$\square$ No
8. What is the biggest challenge facing your downtown's development? $\square$ Quality of Life issues

$\square$ Lack of cooperation between public, private, and non-profit groups

$\square$ Lack of adequate public policy/programs $\square$ Lack of finances for development $\square$ Failure of downtown businesses to compete in the marketplace 口other (Please List)

Thank you for completing this survey!

Please return your survey in the self-addressed envelope. Postage has been pre-paid. 


\section{Curriculum Vitae \\ THOMAS K. BIAS}

Institute for Public Affairs

PO Box 6327

West Virginia University

Morgantown, WV 26506

Email: thomas.bias@mail.wvu.edu
368 Waitman St.

Morgantown, WV 26501

Telephone: 304-685-7077

\section{EDUCATION}

Ph.D. Candidate, Department of Political Science, West Virginia University, Morgantown, WV. Major subfield: Public policy. Research interests: public health policy, state and local politics, survey methodologies, community development. Expected Graduation Date: December 2010.

Masters of Arts, Political Science, West Virginia University, Morgantown, WV. December 2006

Bachelor of Arts, Political Science, West Virginia University, Morgantown, WV. May, 2004.

\section{RELATED JOB EXPERIENCE}

2010-Present Research Specialist 2, Division of Rehabilitation Services, West Virginia Department of Education and the Arts. Responsible developing statistical models for program evaluation and assisting with the development and completion of the annual State Plan.

2006-2010 Assistant Editor, West Virginia Public Affairs Reporter, Institute for Public Affairs, West Virginia University. Assist with day to day responsibilities related to the journal. Reviewing and editing submissions (including selecting and coordinating blind reviewers) and organizing material for printing.

2005-2010 Research Assistant, Institute for Public Affairs, West Virginia University. Responsible for coordinating research and carrying out statistical measurement in a wide variety of policy fields, especially in the area of public health, community development, and survey research. Co-coordination of the West Virginia Local Government Leadership Academy.

\section{OTHER RELEVANT WORK EXPERIENCE}

Website Coordinator, Department of Political Science, West Virginia University. 

Technical School, Hamlin, WV.

\section{PUBLICATIONS}

Bias, Thomas K., Kevin M. Leyden, Christiaan Abildso, Bill Reger-Nash, and Adrian Bauman. "The Leyden Reliability Measurement." Forthcoming in the Journal of Health and Place.

Leyden, Kevin M., Bill Reger-Nash, Jay E. Maddock, Thomas K. Bias, et. al. "Public Health Policy Priorities among Decision Makers in Hawaii". Journal of Physical Activity and Health. May 2009.

Leyden, Kevin M., Bill Reger-Nash, Adrian Bauman, and Tom Bias. "Changing the Hearts \& Minds of Policymakers: An Exploratory Study Associated with the West Virginia Walks Campaign". American Journal of Health Promotion. January/February 2008.

Bias, Thomas K., Richard A. Brisbin Jr. and Kevin M. Leyden. "Citizen Evaluations of West Virginia Government. Stability and Change 1992-2006." West Virginia Public Affairs Reporter. Volume 23, Number 1 .

\section{EDITORIALS AND OTHER NON-PEER REVIEWED PUBLICATIONS}

"Parking a Luxury, Not a Necessity on Campus". Editorial. The Daily Athenaeum. September 8, 2008.

Bias, Thomas K. "Michels, Robert." International Encyclopedia of the Social Sciences, 2008.

\section{MANUSCRIPTS UNDER REVIEW}

Goldberg, Abraham and Thomas K. Bias. "Social Capital and Sustainability." Under Review at The Social Science Journal.

Bias, Thomas K, Abraham Goldberg and Tara Hannum. "Catholics and the Death Penalty: How Religion May Serve as a Filter for Political Beliefs." Under Review at the Journal of Politics and Religion.

Bias, Thomas K. "An Introduction to Small Town Redevelopment Issues". Under Review at the West Virginia Public Affairs Reporter.

\section{MANUSCRIPTS IN PROGRESS}

Bias, Thomas K., Kevin M. Leyden, and Bill Reger-Nash. "Changing the Attitudes of Policymakers Using Public Health Interventions: Survey Instrument and Test-Retest Reliability." 
Leyden, Kevin M., Alan Ducatman, Stephanie Frisbee, and Thomas K. Bias. "A Look at the C8 Health Project (working title)"

\section{SURVEY RESEARCH}

- Designed the 2009 "Local Policymaker Downtown Redevelopment Instrument". In Progress.

- Co-Designed and analyzed the 2008 "Policymaker Survey Reliability Study"

- Co-Designed the 2007 "Hawaii Fruits and Vegetables" Survey.

- Co-Designed the 2007 "Stepping Across Hawaii" Policymakers Survey

- Co-Designed and Implemented the 2007 Brookmar Health Survey.

- Co-Designed and Implemented the 2007 Brookmar Satisfaction Survey.

- Co-Implemented and analyzed the 2005 WV Survey of Citizen Ideology and Participation Analysis presented in the West Virginia Public Affairs Reporter

- Performed co-analysis of the 2005 West Virginia Walks Policymakers Survey.

\section{PRESENTATIONS}

Hannum, Tara M., Thomas K. Bias and Abraham Goldberg. "A Historical Look at Religious Support for the Death Penalty". Presented at the Midwestern Political Science Association Conference. April 22-25, 2010.

Bias, Thomas K., Tara M. Hannum, and Abraham Goldberg. "A Historical Look at Religious Support for the Death Penalty". Presented at a colloquium for the Department of Political Science, West Virginia University. April 9, 2010.

Bias, Thomas K., Tara M. Hannum, and Abraham Goldberg. "Religious, Political, and Social Influences on Public Support for the Death Penalty. Poster for the Eberly College of Arts and Sciences Research Horizons Day, West Virginia University. April 5, 2010.

Bias, Thomas K. "The Politics and Policy of Small City Downtown Revitalization" Presented at the Conference of the Urban Affairs Association. March 11, 2010.

Hannum, Tara M., Thomas K. Bias and Abraham Goldberg. "Religious, Political, and Social Influences on Public Support for the Death Penalty. Presented at the American Criminal Justice Society Annual Conference. February 26, 2010.

Bias, Thomas K. West Virginia University Department of Political Science. "The Politics and Policy of Small City Downtown Revitalization". Colloquium Presentation. November 6, 2009.

Taught a workshop at the West Virginia Local Government Leadership Academy entitled "Development Opportunities for Your Communities". September 2009.

Maddock, Jay E., et. al. $2^{\text {nd }}$ International Congress on Physical Activity and Public Health. "Priority of Active Environment Issues among Key Decision Makers in Hawaii”. Poster Presentation April 2008. 
Bias, Thomas K., Kevin M. Leyden, Bill Reger-Nash, Jay E. Maddock, and Adrian Bauman. Robert Wood Johnson Foundation Active Living Conference. "Changing Attitudes of Policymakers. Using Public Health Interventions: Survey Instrument and Test-Retest Reliability." Poster Presentation. April 11, 2008.

Bias, Thomas K and Arian Spahiu. "Lobbying in West Virginia." Poster presentation at the WVU Eberly College of Arts and Sciences Research Horizon Day. March 2008

Scotto, Thomas, Gerald Lackey, Arian Spahiu, and Thomas K. Bias. "Religion and Partisanship in the United States". Poster presentation at the WVU Eberly College of Arts and Sciences Research Horizon Day. March 2008.

Leyden, Kevin, Bill Reger-Nash, Adrian Bauman, and Thomas K. Bias. West Virginia University Presidential Inauguration Research Day. "Changing the Hearts \& Minds of Policymakers:An Exploratory Study Associated with the West Virginia Walks Campaign". Poster Presentation. November 2007.

Taught a workshop at the West Virginia Local Govemment Leadership Academy entitled "Local Govermment Policy Problems and Solutions". April 2007

Leyden, Kevin, Bill Reger-Nash, Adrian Bauman, and Thomas K. Bias. Eberly College of Arts and Sciences Poster Session. "Changing the Hearts \& Minds of Policymakers:An Exploratory Study Associated with the West Virginia Walks Campaign". Poster Presentation. April 2007

Bias, Thomas K and Arian Spahiu. "Lobbying in West Virginia." Paper Presented at the West Virginia Political Science Association, Fall 2006.

Scotto, Thomas, Gerald Lackey, Arian Spahiu, and Thomas K. Bias. "Religion and Partisanship in the United States". Paper presentation at the American Political Science Association Annual Meeting 2006 .

Interview on West Virginia Public Radio about "Citizen Evaluations of West Virginia Government: Stability and Change 1992-2006" on May 1, 2006.

Bias, Thomas K., Richard A. Brisbin Jr. and Kevin M. Leyden. "Citizen Evaluations of West Virginia Government: Stability and Change 1992-2006." Paper Presented at the West Virginia Political Science Association, Fall 2005.

\section{PROFESSIONAL DEVELOPMENT AND SERVICE}

\section{Teaching}

- West Virginia Government - Political Science 321, Fall 2008 Semester 


\section{Grants}

- Assisted with a 2008 National Institute of Health Grant with Reger-Nash, Bill, et. al. Under Revision for Re-submission.

- Assisted with the 2007 West Virginia Development Office Flex-E-Grant. "Encouraging New Leaders". Awarded \$10,000.

\section{Service}

- Co-Coordination of the Center for Advancement of Leadership Skills conference in Morgantown, WV. October 2009

- Coordination of the West Virginia Local Government Leadership Academy conference in Charleston, WV Fall 2009.

- Co-Coordination of the West Virginia Local Government Leadership Academy. Fall 2005Spring 2010.

- Chairman - Morgantown Pedestrian Safety Board, 2007-2008

- Blind Reviewer of Submissions, Joumal of Politics, 2005-2006.

- Alumni Representative, Congressional Youth Leadership Council (Washington, DC), 19982000 .

\section{Professional Development}

- Collaborative Institutional Training Initiative Courses Completed (Research Ethics Training). Spring 2008.

- Southem Growth Policy Board meeting. Summer 2007.

- ESRI ArcGIS training, West Virginia GIS Training Center, Winter, 2006.

\section{Software Programs}

STATA, SPSS, SAS, LISREL, Microsoft Office, WordPerfect, HTML, Adobe Dreamweaver, Adobe Acrobat Professional, Adobe Photoshop, GIS software, Autocad, Visual Basic, C, ADA.

\footnotetext{
John H. Virginia University Libraries, 